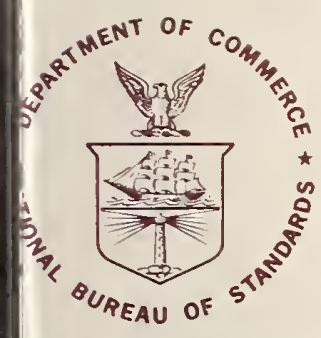

NBS TECHNICAL NOTE 978

U.S. DEPARTMENT OF COMMERCE / National Bureau of Standards

\title{
Nationwide Survey of Cobalt-60 Teletherapy Dosimetry
}


The National Bureau of Standards ${ }^{1}$ was established by an act of Congress March 3, 1901. The Bureau's overall goal is to strengthen and advance the Nation's science and technology and facilitate their effective application for public benefit. To this end, the Bureau conducts research and provides: (1) a basis for the Nation's physical measurement system, (2) scientific and technological services for industry and government, (3) a technical basis for equity in trade, and (4) technical services to promote public safety. The Bureau's technical work is performed by the National Measurement Laboratory, the National Engineering Laboratory, and the Institute for Computer Sciences and Technology.

THE NATIONAL MEASUREMENT LABORATORY provides the national system of physical and chemical and materials measurement; coordinates the system with measurement systems of other nations and furnishes essential services leading to accurate and uniform physical and chemical measurement throughout the Nation's scientific community, industry, and commerce; conducts materials research leading to improved methods of measurement, standards, and data on the properties of materials rieeded by industry, commerce, educational institutions, and Government; provides advisory and research services to other Government Agencies; develops, produces, and distributes Standard Reference Materials; and provides calibration services. The Laboratory consists of the following centers:

Absolute Physical Quantities ${ }^{2}$ - Radiation Research - Thermodynamics and Molecular Science - Analytical Chemistry - Materials Science.

THE NATIONAL ENGINEERING LABORATORY provides technology and technical services to users in the public and private sectors to address national needs and to solve national problems in the public interest; conducts research in engineering and applied science in support of objectives in these efforts; builds and maintains competence in the necessary disciplines required to carry out this research and technical service; develops engineering data and measurement capabilities; provides engineering measurement traceability services; develops test methods and proposes engineering standards and code changes; develops and proposes new engineering practices; and develops and improves mechanisms to transfer results of its research to the utlimate user. The Laboratory consists of the following centers:

Applied Mathematics - Electronics and Electrical Engineering ${ }^{2}$ - Mechanical

Engineering and Process Technology ${ }^{2}-$ Building Technology - Fire Research -

Consumer Product Technology - Field Methods.

THE INSTITLTE FOR COMPUTER SCIENCES AND TECHNOLOGY conducts research and provides scientific and technical services to aid Federal Agencies in the selection, acquisition, application, and use of computer technology to improve effectiveness and economy in Government operations in accordance with Public Law 89-306 (40 U.S.C. 759), relevant Executive Orders, and other directives; carries out this mission by managing the Federal Information Processing Standards Program, developing Federal ADP standards guidelines, and managing Federal participation in ADP voluntary standardization activities; provides scientific and technological advisory services and assistance to Federal Agencies; and provides the technical.foundation for computer-related policies of the Federal Government. The Institute consists of the following divisions:

Systems and Software - Computer Systems Engineering - Information Technology.

Headquarters and Laboratories at Gaithersburg, Maryland, unless otherwise noted; mailing address Washington,D.C. 20234.

${ }^{2}$ Some divisions within the center are located at Boulder, Colorado, 80303. 


\section{Nationwide Survey of Cobalt-60 Teletherapy Dosimetry}

C.G. Soares

M. Ehrlich

Center for Radiation Research

National Measurement Laboratory

National Bureau of Standards

Washington, D.C. 20234

Sponsored by

Radioactive Materials Branch

Bureau of Radiological Health

Rockville, Maryland 20852

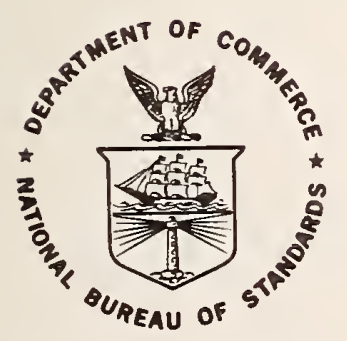

U.S. DEPARTMENT OF COMMERCE, Juanita M. Kreps, Secretary

Dr. Sidney Harman, Under Secretary

Jordan J. Baruch, Assistant Secretary for Science and Technology

U s. NATIONAL BUREAU OF STANDARDS, Ernest Ambler, Director

Issued August 1978 
National Bureau of Standards Technical Note 978

Nat. Bur. Stand. (U.S.), Tech. Note 978,40 pages (Aug. 1978) CODEN: NBTNAE

U.S. GOVERNMENT PRINTING OFFICE

WASHINGTON: 1978

For sale by the Superintendent of Documents, U.S. Government Printing Office, Washington, D.C. 20402 Stock No. 003-003-01968-2 Price $\$ 1.60$

(Add 25 percent additional for other than U.S. mailing). 


\section{Contents}

Page

1. Introduction . . . . . . . . . . . . . . . . . . . . . . . 1

2. Administrative Procedure . . . . . . . . . . . . . . . . . . . . 1

2.1 Contacting the Prospective Participants . . . . . . . . . . . 1

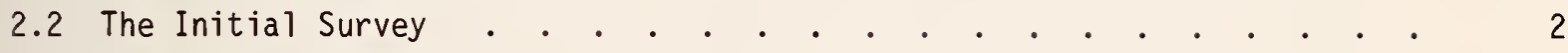

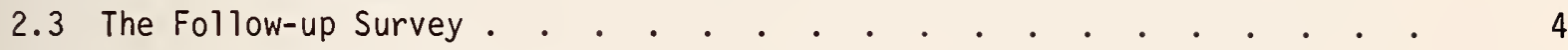

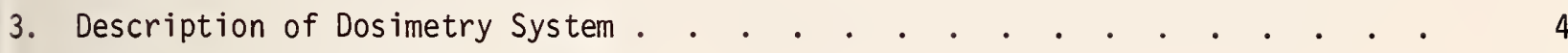

3.1 Choice of Detector . . . . . . . . . . . . . . . . . . . . . . . . . . . 4

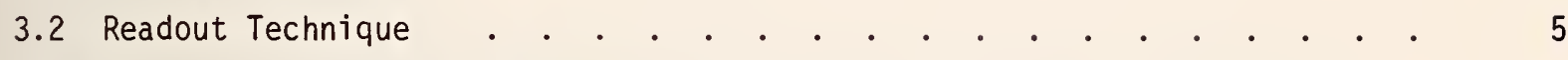

4. Dose Interpretation From TL Response . . . . . . . . . . . . . .7

4.1 Method . . . . . . . . . . . . . . . . . . . . . . 77

4.2 Uncertainties in NBS Method
of Determining Absorbed Dose from Dosimeter Response . . . . . . . . . 12

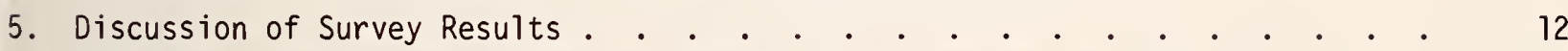

5.1 Dose Interpretation from Response of Irradiated Dosimeter . . . . . 12

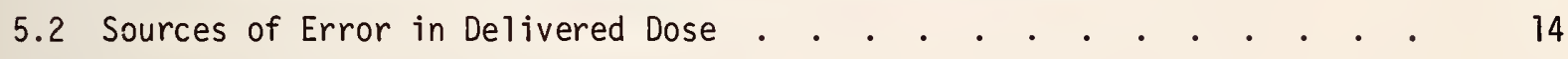

6. Comparison With Results of Others . . . . . . . . . . . . . . $\quad 18$

7. Acknowledgement . . . . . . . . . . . . . . . . . . . . 19

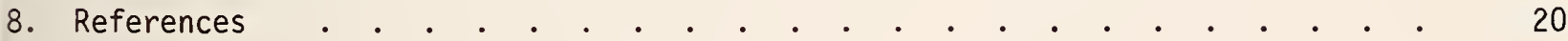

Figures . . . . . . . . . . . . . . . . . . . . . . . . in text

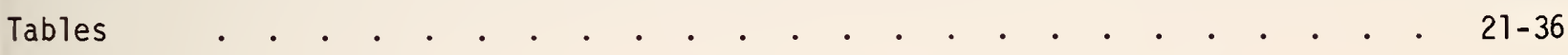


Between September 1974 and December 1977 the National Bureau of Standards, in cooperation with the Bureau of Radiological Health, performed a study of the accuracy with which a prescribed absorbed dose of cobalt-60 gamma radiation is delivered to a specified point in a water phantom. Approximately two-thirds of the cobalt-60 teletherapy units in the U.S. were surveyed by mai1, using a rugged thermoluminescence dosimetry system. The dose given by participants was evaluated from dosimeter response, and information supplied by participants was used to check their computations of the dose delivered. In this nationwide study, 83 percent of the units surveyed yielded dose interpretations within 5 percent of the requested dose, 13 percent yielded differences between 5 and 10 percent, and 4 percent of the dose interpretations differed by more than 10 percent from the dose requested. Sources of discrepancies are discussed, and the results of this survey are compared with those of other dosimetry surveys.

Key words: Absorbed dose; coba $1 t-60$ gamma radiation; computation check; dose interpretation; mailings; survey; teletherapy; thermoluminescence dosimeters; water phantom.

\section{INTRODUCTION}

Cobalt-60 gamma ray teletherapy sources are widely used for cancer therapy, both in this country and around the world. The accuracy with which a prescribed absorbed dose is delivered to a tumor has been shown to be crucial to treatment success. (1) In order to assess the ability of cobalt-60 teletherapy users in the United States to deliver a prescribed dose of radiation to a water phantom, the National Bureau of Standards (NBS) has carried out a measurement assurance program using mailed thermoluminescence dosimeters. Other programs of this type have been successful in assessing the performance of cobalt-60 teletherapy users elsewhere (see sec. 6). The survey described in this paper includes over two-thirds of the approximately 1000 teletherapy facilities currently in use in this country.

\section{ADMINISTRATIVE PROCEDURE}

\subsection{Contacting the Prospective Participants}

Lists of teletherapy licensees were supplied to NBS by the Bureau of Radiological Health $(B R H)$ at a rate of one list of about 50 licensees every six weeks. Each licensee was sent a form letter (table 1 ) which explained the purpose of the survey and asked for voluntary participation. Table 2 is a copy of the questionnaire which was included for the recipient to indicate whether or not he was willing to participate. This form was to be returned to NBS in a stamped self-addressed envelope which was enclosed. If there was no response from the licensee after four weeks, a follow-up form letter was sent (table 3 ), including the same questionnaire and return envelope. This approach was quite useful in obtaining additional participants. Almost half of the licensees who were sent follow-up 
Over the three years of the survey, there were 1020 licensees' names and addresses supplied by BRH. All but 144 licensees returned the questionnaire. Of those returning the questionnaire, 656 indicated willingness to participate*, while 74 refused participation. The remaining 146 indicated that they did not have a cobalt-60 teletherapy unit at the time of inquiry.

\subsection{The Initial Survey}

The initial survey comprised 24 mailing cycles, each approximately six weeks long and consisting of the following phases:

\section{a. Mailing Phase}

Each mailing involved between 35 and 50 sets of six dosimeters. Approximately ten days before the dosimeters were to be mailed, licensees who had expressed willingness to participate were sent an announcement (table 4) that the dosimeters were to be mailed soon. Then, at the beginning of the six-week mailing cycle, one set of dosimeters was mailed to the participants for each cobalt-60 teletherapy beam to be surveyed. Included with each set was a copy of the announcement sent the previous week, instructions for irradiation of the dosimeters, and an information form for the participant to complete.

The instruction form is shown in table 5. The participants were asked to compute the time necessary to deliver 3.0 grays ( 300 rad) at a depth of 1 centimeter in a large water phantom for a $10 \mathrm{~cm} \times 10 \mathrm{~cm}$ field size and their normal treatment distance. They were then to irradiate 5 of the 6 dosimeters in air, on top of the cardboard shipping carton, for this time at this distance. The sixth dosimeter was to be left blank as a control. The essentials of the prescribed irradiation geometry are shown in figure 1. Participants were asked that the irradiations be perfomed under conditions duplicating as closely as possible the routine patient irradiations, and that the individuals carrying out the irradiations be those routinely involved in snt set-up and treatment.

The three-page information form $(\ldots 26)$ was in two parts. In the first part (page 1) the participant was asked to supply time and date of irradiation, distance, field size, irradiation time, and identification of the person doing the exposures and the person supplying the information. This page could be readily completed by a technician and was to be returned with the dosimeters. The second part (pages 2 and 3) was to be filled out by the physicist in charge. It required information about beam calibration and parameters used by the participant to detemine the absorbed-dose rate used for the dosimeter irradiations. This latter information was used by NBS to check the participant's absorbed-dose computation.

\section{b. Evaluation and Reporting Phase}

After the dosimeters had been returned to NBS by the participants, dose interpretations from dosimeter responses were made, according to the procedure described in section 4.1 .

*Some of these licensees had more than one cobalt-60 teletherapy unit to be surveyed. 
PRESCRIBED IRRADIATION GEOMETRY

SSD

TECHNIQUE

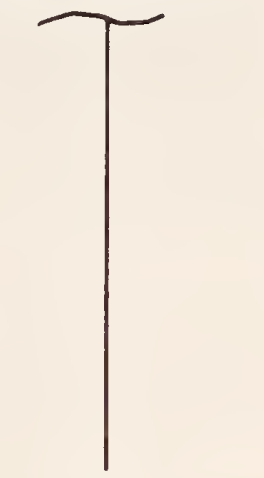

SSD

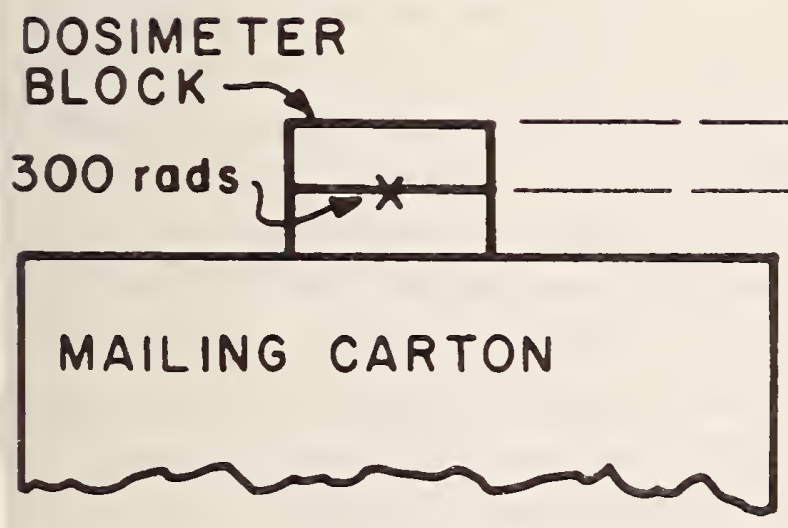

Figure 1. Prescribed Irradiation Geometry. The participant was to employ his usual distance and technique (either source-to-surface, SSD, or source-to-axis, SAD). 
This generally occurred during the fifth and the sixth week of the mailing cycle. Upon completion of this evaluation, each participant was sent the absorbed-dose interpretation obtained from the response of each dosimeter involved in the particular mailing, with his own dosimeters identified. Also included were: the value of absorbed dose as computed by NBS from the calibration information (if supplied by the participant), tables of factors and methods used in this computation, and some general information about the survey. The text of the report is given in table 7 . Table 8 shows the various methods used to compute absorbed-dose rate at a l-centimeter depth in a water phantom. The factors employed in the computation are listed in table 9. Copies of the reports were given to the Bureau of Radiological Health but without participant identification. (Performance of all participants is known only to NBS and is treated as confidential information.)

\subsection{The Follow-up Survey}

As a part of the last mailing cycles of the initial survey and in one additional mailing cycle, follow-up studies were performed. They were:

\section{a. Statistical Verification of Survey Results}

A sub-sample of the original participants was selected for further work. The chosen sub-sample consisted of 10 percent of the participants whose results were within 5 percent of the requested dose, one-haif of the participants whose results differed fram the requested dose by between 5 and 10 percent, and all participants whose results differed by more than 10 percent. A total of 143 participants were involved in this re-study.

\section{b. Check on Influence of Incomplete Participation}

It was furthermore desired to assess the influence upon the statistical survey results of the fact that certain licensees had declined to participate or had not responded to the initial invitation to participate. For this purpose, a randomly selected sample of 10 percent of this group was contacted and 13 of them were persuaded to participate at the end of the survey. It was impossible to determine exactly how many of the licensees who did not respond to the initial inquiries were no longer using a cobalt-60 therapy unit. However, during the selection of participants from the non-respondents, it was found that one-third, or 7 of the 21 licensees selected, were no longer doing cobalt-60 therapy. If this ratio is applied to the entire group of non-respondents, then the 13 licensees who were persuaded to participate in the last round represent eight percent of the licensees who had not responded or declined to participate in the original survey.

\section{DESCRIPTION OF DOSIMETRY SYSTEM}

\subsection{Choice of Detector}

A mailable dosimetry system should be suitable for storing irradiation information and should be mechanically rugged and thermally stable. For these reasons, thermoluminescence (TL) detectors are generally chosen for mailed systems. They do exhibit a certain amount of fading of the stored information, but the fading characteristics are well known. Also, since ours was to be a long-term project covering a large number of facilities with relatively few dosimeters, it was necessary for the chosen detector to withstand repeated use. 
Thus, the TL material chosen had to have a relatively small dependence of TL response on thermal and irradiation history. For this reason, $\mathrm{CaF}_{2}: \mathrm{Mn}$ was selected. The commercially available dosimeters consisted of two pieces of pressed crystalline $\mathrm{CaF}_{2}: \mathrm{Mn}_{\text {in }}$ contact with a metallic heater strip, enclosed in a quartz bulb with a neutral atmosphere. During shipment and irradiation, these bulbs were encased in black polystyrene blocks, as shown in figure 2. One bulb each was placed into one of the halves of a block, each half having dimensions $7.6 \mathrm{~cm} \times 5.0 \mathrm{~cm} \times 1.0 \mathrm{~cm}$. The halves were then screwed together with Nylon screws. The plastic was of sufficient thickness for maximum electron buildup in polystyrene at the bulb surface in a cobalt-60 gamma ray beam. Black plastic was chosen since $\mathrm{CaF}_{2}: \mathrm{Mn}$ is sensitive to prolonged exposure to visible light. The orientation of the bulb with respect to the incident beam was fixed by bending one of the bulb pins. This also fixed the orientation during readout, which was found to be necessary for good reproducibility. The orientation chosen was such that neither of the TL pieces in the bulb was shielded from the gamma ray beam by the heater strip, and that luminescence emission was not blocked by the heater strip during readout.

Initially 280 bulbs were used for the survey. They were divided into two batches. The first batch, purchased earlier, consisted of 88 dosimeters numbered from 3 through 91. The second batch of 192 was numbered from 101 through 292. The two batches differed from each other mainiy in their average response, the former batch being more sensitive than the latter batch. In order to increase the number of teletherapy units surveyed per mailing cycle an additional set of 100 bulbs was purchased during the course of the survey. This third batch was assigned numbers from 301 through 400 . Its sensitivity was about midway between the two earlier batches.

\subsection{Readout Technique}

The dosimeters were read out in a commercial assembly which included a buib-heating unit using resistive heating of the heater strip, and a cooled photomultiplier for converting light output to electric current. A current integrator was used to determine the total TL signal, which was transferred automatically to paper tape upon completion of readout. For flexibility in the selection of readout parameters, the entire assembiy was controlled by an electronic timer in a circuit designed at NBS to permit independent variation of total heating and current-integration times.

Since the TL dosimetry system employed relied on annealing of the $\mathrm{CaF}_{2}: \mathrm{Mn}_{\text {material }}$ solely during readout, a readout technique was chosen that enabled one to read dosimeters irradiated over the entire contemplated dose range without appreciable interference from incandescence or from release of residual trapped electrons. Yet, to prolong the life of the dosimeters, heating power was kept at a minimum. An annealing time of 21 seconds was used throughout. For readout of dosimeters mailed to the participants and of all associated calibration dosimeters which received exposures of 100 roentgens or more, the heater current was 6.0 amperes, which produced close to the highest permitted thermal load to the dosimeter. For the three further readouts required during each cycle, a heater current of 5.5 amperes was sufficient. For details on calibration and readout see section 4.1 . 


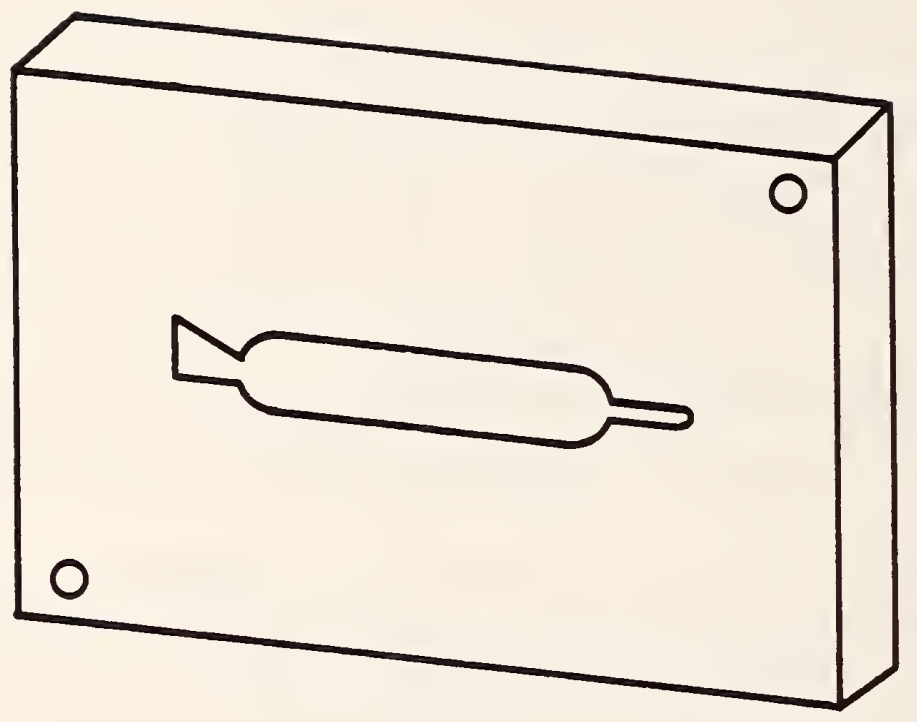

‥
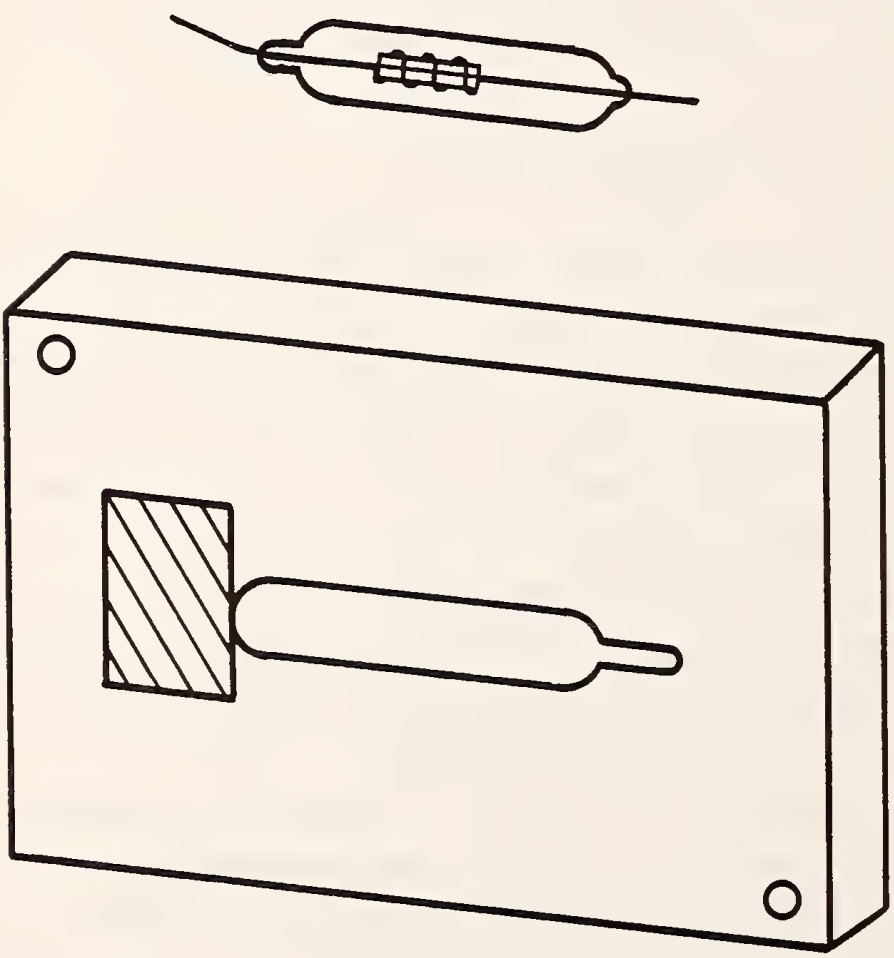

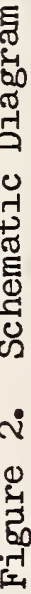


Initially, signal-integration times of 14 and 16 seconds for the 6 - and 5.5-ampere readouts, respectively, were used since they were found to produce maximum discrimination against incandescence, while including most of the glow peaks. However, these integration times were not sufficient for the readout of the most recently acquired batch of TL dosimeters, whose main glow peaks lay at slightly higher temperatures than those of the older batches. Thus, the integration times for all the dosimeters were changed to 16 and 19.5 seconds for the 6-and 5.5-ampere readouts, respectively. With these longer integration times, it was still possible to discriminate successfully against incandescence. Figure 3 shows typical glow curves, with the beginning and the end of the current-integration periods noted.

\section{DOSE INTERPRETATION FROM TL RESPONSE}

\subsection{Method}

Prior to their initial use in the program, all dosimeters were administered a series of ten identical cobalt-60 gamma ray exposures between 3 and 5 roentgens and were read out by the method described below. The results of these successive readings yielded initial values of individual response per unit exposure (sensitivity) and indications of the extent of reproducibility of dosimeter response. The relative standard deviation of repeated individual dosimeter readings was found to range from about 0.1 to 2 percent, with an average of 0.8 percent.

During each mailing cycle, each dosimeter was read four times. The first readout yielded the raw dosimeter response to the irradiation administered by the participant (or by NBS if that dosimeter had been kept at NBS for use in the calibration procedure). The three subsequent readouts were for correction purposes. Five days after the first readout, each dosimeter was read a second time, for a determination of its residual response level. Then on the next two days, each dosimeter was exposed to the same low level ( 3 to 5 R) and read out approximately 4 hours later, for a determination of its individual sensitivity. The data from each of the four readouts were fed into a Univac 1108 computer, and were analyzed by a program developed for the purpose. This program used an algorithm involving the determination of absorbed dose received by a dosimeter from dosimeter response, corrected for (a) relative sensitivity of the dosimeters to cobalt-60 gamma radiation, (b) change in photomultiplier sensitivity during readout, and (c) fading. The following is a discussion of these three corrections:

(a) The sensitivity of each dosimeter was checked between successive mailings. This was necessary since sensitivity was found to change with repeated use, as is illustrated in figure 4. A correction for the difference in response of individual dosimeters was determined by exposing each dosimeter to the same low level ( 3 to $5 \mathrm{R}$ ) of cobalt-60 gamma radiation, with the time intervals between irradiation and readout adjusted to eliminate the need for fading corrections. The average of the responses after two such exposures, performed on successive days, formed the basis of the sensitivity correction for each dosimeter.* A further correction was required for each dosimeter because of the presence of

* It might have been preferable to use as the basis for the sensitivity correction the mean of the two response values before and after a given irradiation-and-readout cycle. This would have tended to average out the fluctuations in the sensitivity changes recorded between successive irradiation and readout cycles (see fig. 4). 


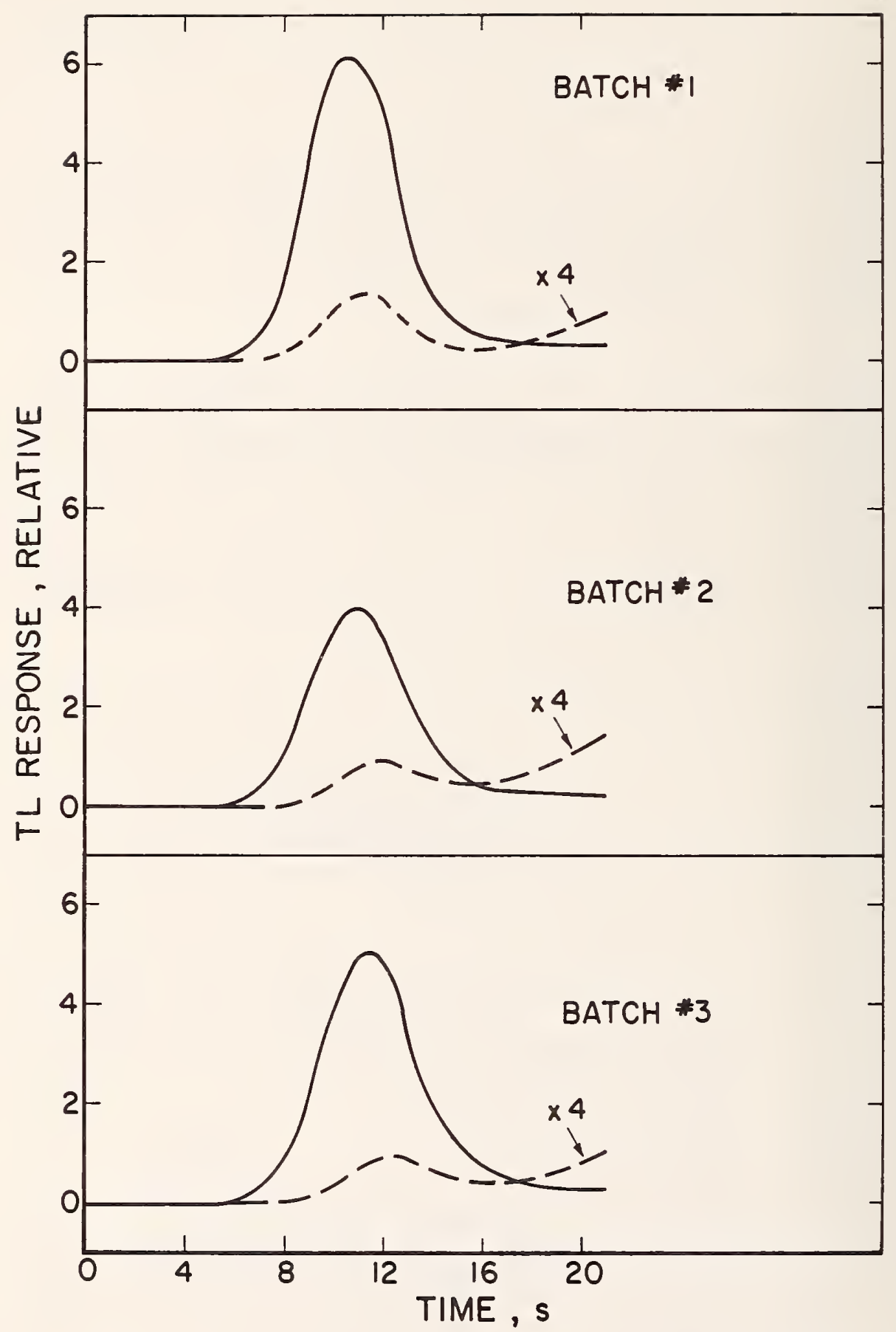

Figure 3. Typical Glow Curves for the Three Dosimeter Batches. The continuous lines represent the response to a 3-5 $\mathrm{R}$ exposure, while the dashed line (drawn with the ordinate multiplied by four) represents the sum of the residual glow curve from a previous $300-R$ exposure, and incandescence. The current-integration period started at time zero and extended to 19.5 seconds. 


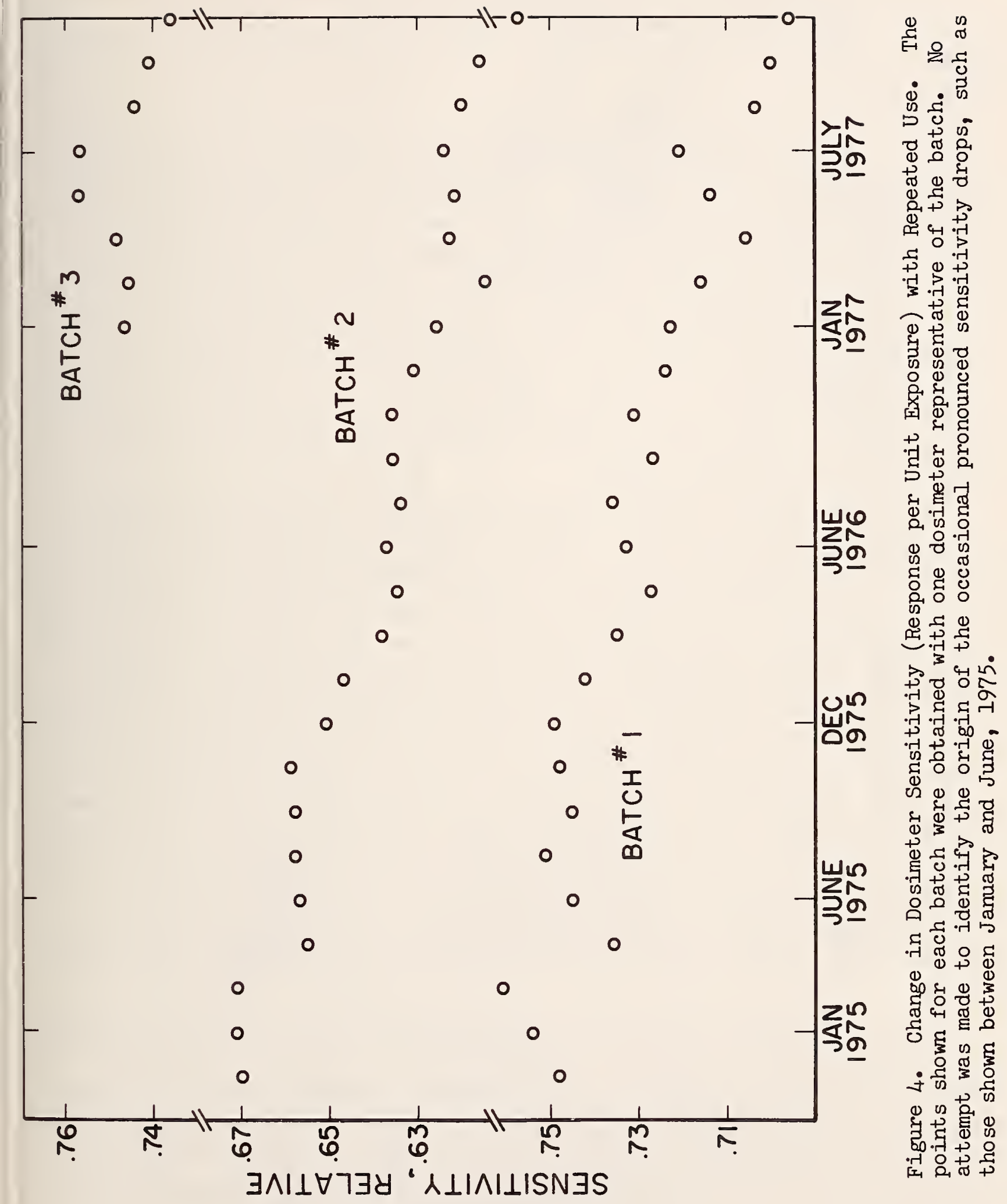


residual thermoluminescence, the magnitude of which depended upon the absorbed dose received during the mailing cycle. This residual"TL was measured in a second readout of each dosimeter five days after the first readout. For the irradiation and readout sequence employed, this correction amounted to between 0.5 and 1.5 percent of the response to a 3 to 5 roentgen exposure.

(b) A correction for change of photomultiplier sensitivity during readout was necessary. To convert the TL signal to an electric current for integration, a bialkali-dynode type photomultiplier was used at 620 volts. This voltage led to current signals of about 10 microamperes for the TL response to 300 rads. Under these operating conditions, the photomultiplier gain was found to increase monotonically by almost 4 percent during the roughly 3 hours required for the readout of about 270 dosimeters, of which about 200 received $\sim 300$ rads. A suitable correction for this increase was obtained with the aid of readings taken at regular intervals during the readout sequence of the constant light source built into the reader. This gain change was probably due to insufficient cooling of the photomultiplier at high signal levels, since an overhaul of the cooling fan motor decreased the effect considerably. After this overhaul was performed, the gain change during readout was never larger than 2 percent.

(c) During the three years of the survey, fading characteristics of the dosimeters were monitored at regular intervals. Initially the reduction of the TL signal with an increase in the delay between irradiation and readout ("fading") was found to be about 4 percent over the decade between 20 and 200 hours, while it was only about 2.5 percent over the subsequent 500 hours. In the course of the survey, it was noticed that the first dosimeter batch (lowest numbers) was fading to a lesser extent than the other batches, and that it was therefore necessary to apply two different fading corrections, one for the first batch and one for the other two batches, which were found to exhibit the same degree of fading. An example of the fading behavior is shown in figure 5, where TL response relative to that obtained in a readout 24 hours after irradiation is plotted against time in hours between irradiation and readout. From the figure it is seen that the correction for fading applied to the readings of the dosimeters exposed by the participants varied between 3 and 7 percent for the usually encountered 170-to-700-hour delay between irradiation and readout. The time and date of irradiation, supplied by the participants on page 1 of the information form (table 6) gave us the data necessary for the application of the appropriate fading correction.

The corrected dosimeter response was obtained by applying each of the above corrections to the raw response data. Implicit in this procedure is the assumption that relative dosimeter sensitivity is independent of irradiation level. Absorbed dose was derived from the corrected response with the aid of an absolute dosimeter calibration carried out by administering known cobalt-60 gamma ray exposures to a group of dosimeters in a geometry identical to that used by the participants. Several dozen dosimeters were employed, with the absorbed dose delivered being computed from exposure using method 3 (table 8 ) and parameters from table 9 . These calibration dosimeters were read out along with the 


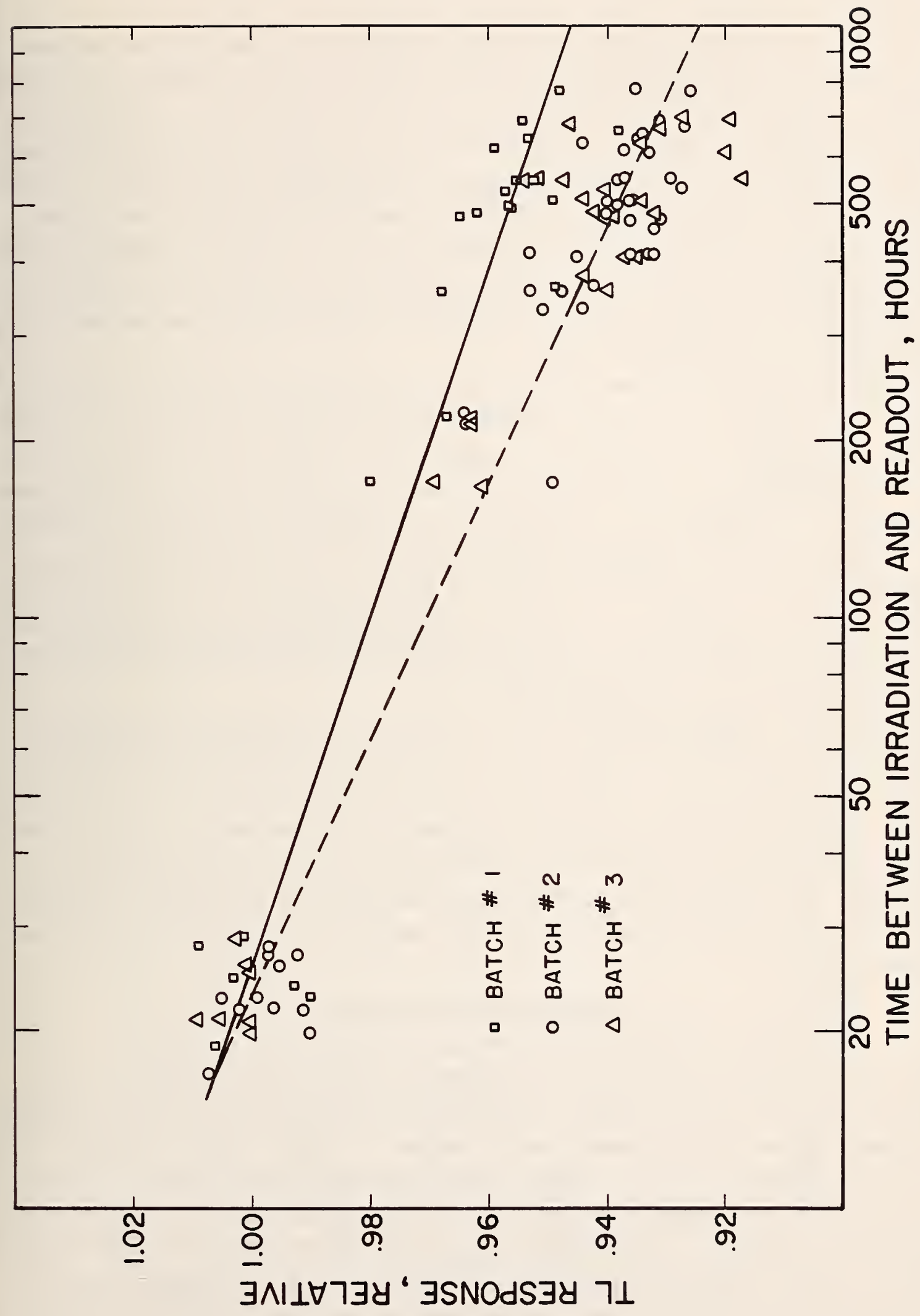

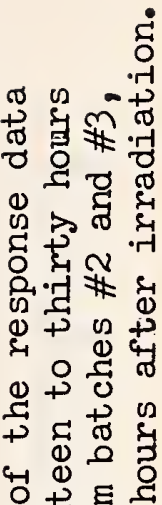
$0+$ 틍 로 +त क्ष प्त मु फै

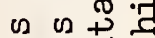
(1) + ริ วิ 궁 $\infty$ 何 क \& ट \& स

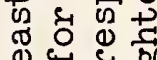
(1) द्न क्ष ఫ્વ घ. मे .

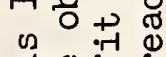
ว 올 ڤ . + ⿰ 丶万⿱ 今 (1) 1 .

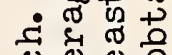
บ \& \& + ๓ 0.

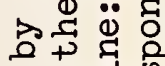
की 당 잉 덩 ఫ્ع ه ชู ज ส [. न्न \& 岂 ह क न्मे क 다 ర - डै ह nो + है ๑ ص द्व म्न द्य क्ष 
dosimeter returned by the participants, and were handled identically in subsequent readouts and irradiations.

4.2 Uncertainties in NBS Method of Determining Absorbed Dose from Dosimeter Response

A valid assessment by NBS of the participants' ability to deliver a prescribed absorbed dose necessitated a knowledge of the uncertainty in the NBS procedure for determining absorbed dose from dosimeter response. In table 10, values are given for the systematic and random uncertainties inherent in the NBS procedure for determining absorbed dose. The systematic uncertainties, stemming from the use of dosimeter-calibration and fading curves, were obtained from the least-squares fits of these curves. The individual systematic uncertainties were taken to be three times the average standard deviations of the predicted values in the ranges of interest. The total systematic uncertainty then was derived as the sum of the individual uncertainties listed.

The total random uncertainty was determined by considering both the limits in the reproducibility of the response of any one dosimeter (obtained prior to the start of the survey, see sec. 4.1), and the variation in the response from dosimeter to dosimeter. The limit in the reproducibility of the response was taken to be three times the relative standard deviation, $S$, of the readings of a dosimeter after repeated irradiations and readouts $(2.4 \%)$. This same reproducibility limit also is reflected in the correction factor applied to the reading of an individual dosimeter, to take into account the variation in response from dosimeter to dosimeter. The total random uncertainty in the determination of absorbed dose from dosimeter response then was computed as the square root of the sum of the squares of these two uncertainties $(3.4 \%)$.

The corresponding random uncertainty of the average of the absorbed-dose values obtained from the readings of five dosimeters then was obtained by division by $\sqrt{5}$, finally leading to an estimate of about 4 percent (or \pm 12 rad at the 300 -rad level) for the algebraic sum of the uncertainty due to the total systematic and random errors. This is taken to be the total uncertainty of the NBS dose interpretation from the average response of five dosimeters. The hard-to-assess uncertainties associated with the generally accepted values of the parameters and constants used in the computation of absorbed dose from exposure were not included.

\section{DISCUSSION OF SURVEY RESULTS}

\subsection{Dose Interpretation from Response of Irradiated Dosimeters}

Figure 6 shows the distribution of the differences between the absorbed dose of 300 rads to be delivered by the participants and the NBS dose interpretations from the average of the responses of the five dosimeters they irradiated. The total number of dosimeter sets involved was 906, of which 751 or 83 percent yielded dose interpretations with \pm 5 percent of the requested dose of 300 rads in water. In view of the error analysis presented in the previous section, differences of 5 percent or more (in either direction) in the average dose interpretation must be considered significant. Seventeen percent or 155 sets yielded dose interpretations differing by more than 5 percent from the requested dose, with 34 of these (4\%) differing by more than 10 percent. This distribution can be replaced by a Gaussian 


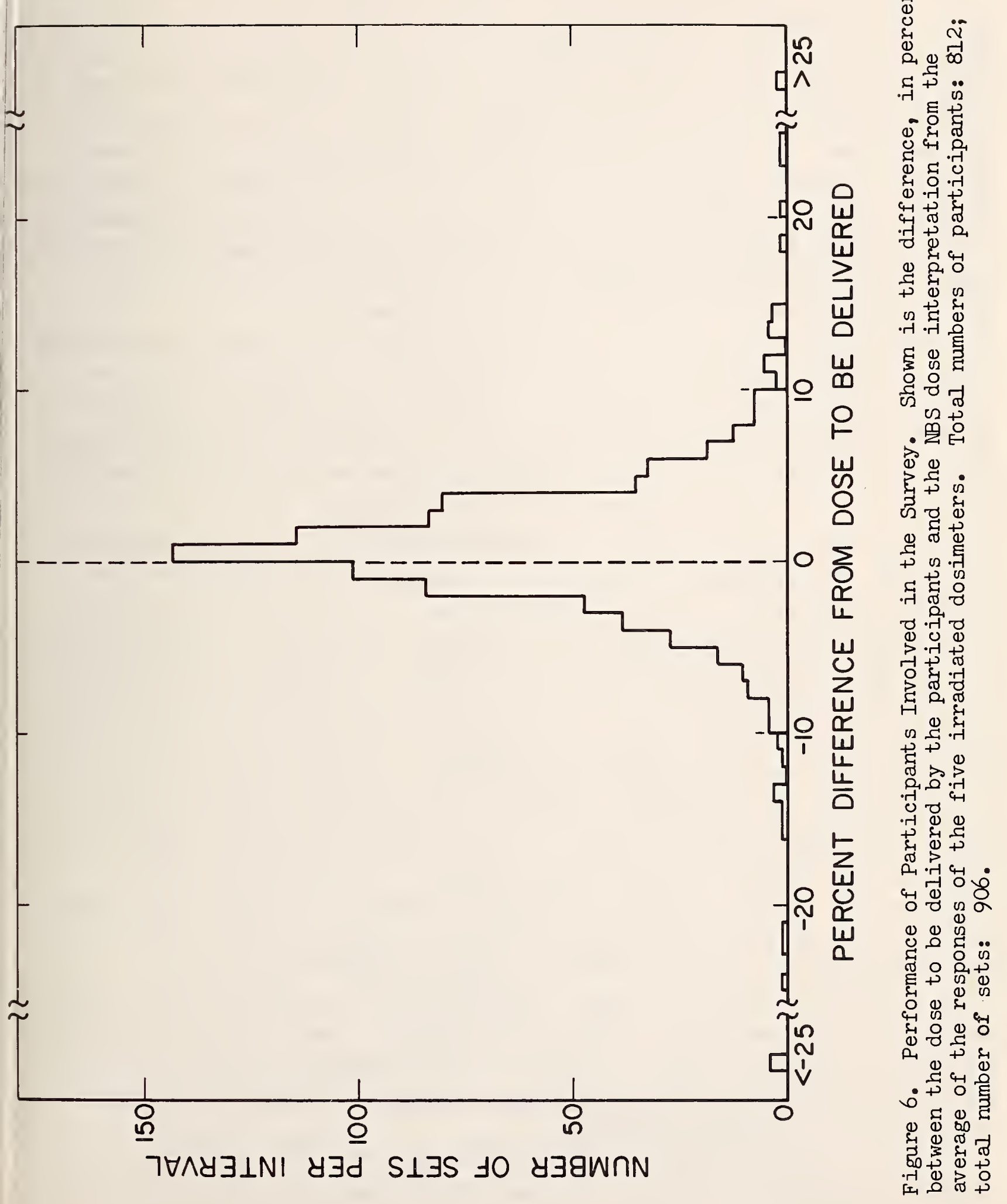


envelope with a width, $\sigma$, of 3.8 percent. There is a positive bias in the data, the average deviation for all sets shown being +0.7 percent. We believe that the reason for this bias is that most participants used the conversion factor from exposure to absorbed dose in soft tissue (.957) rather than that to absorbed dose in water (.965) which was used at NBS in the dosimeter calibrations. (For the purposes of this study, we did not make a distinction between absorbed dose in soft tissue and water, see table 5). The results for the participants who were selected for a re-survey are shown in figure 7 . There was a definite improvement in the group for which the dose delivered initially differed from 300 rads by more than 10 percent. The survey results of the 143 selected participants show essentially the same performance breakdown as the group as a whole, i.e., 83 percent within 5 percent, 12 percent between 5 and 10 percent, and 5 percent with deviations outside of 10 percent. This is interesting because this group contained most of the participants who had performed poorly, but only 10 percent of those who had performed well.

A histogram of the results for the sample of initial non-participants who participated at the end of the survey is shown in figure 8. Although the statistics are poor, they indicate the same performance breakdown as for the other groups surveyed. Hence there is reason to believe that the fact that some licensees did not respond to the initial communications or refused to participate did not detract from the generality of our results.

\subsection{Sources of Error in Delivered Dose}

Only through laboratory visits is it possible to isolate all sources of error in performance. The NBS study did not involve any laboratory visits. However, from the information forms returned with the dosimeters, it was often possible to separate errors in calculation of the absorbed-dose rate from errors in dose delivery. Distinct from both of these were discrepancies which arose because participants misread or misunderstood the instructions. Thus, in the course of the survey, we received dosimeters which had been irradiated to 30, 200, 900 or 100 rads. The latter value occurred more than once, undoubtedly because of confusion caused by the concurrent Nuclear Regulatory Commission TLD survey. This type of misunderstanding of the instructions accounts for the discrepancies greater than 25 percent shown in figure 6 . We were able to ascertain that further errors resulted when participants failed to place the dosimeters on the shipping carton for irradiation. This generally resulted in larger dose interpretations than expected because of an increase in the back-scatter contribution to the dosimeter response. Also, irradiating dosimeter blocks upside-down sometimes led to small deviations $(<4 \%)$.

A relatively large number of errors concerned delivery of the prescribed dose. The most common one involved improper setting of the mechanical timer by one minute in either the positive or negative direction. This error was identified 15 times in the course of the approximately 4500 doses that were delivered, indicating that the timer systems in general use may be in need of improvement.

We later learned that other delivery errors had resulted from irradiation at improper distances, transposition of digits in treatment times, attenuators not accounted for, dosimeters irradiated twice by mistake, and errors caused by timer and other equipment 


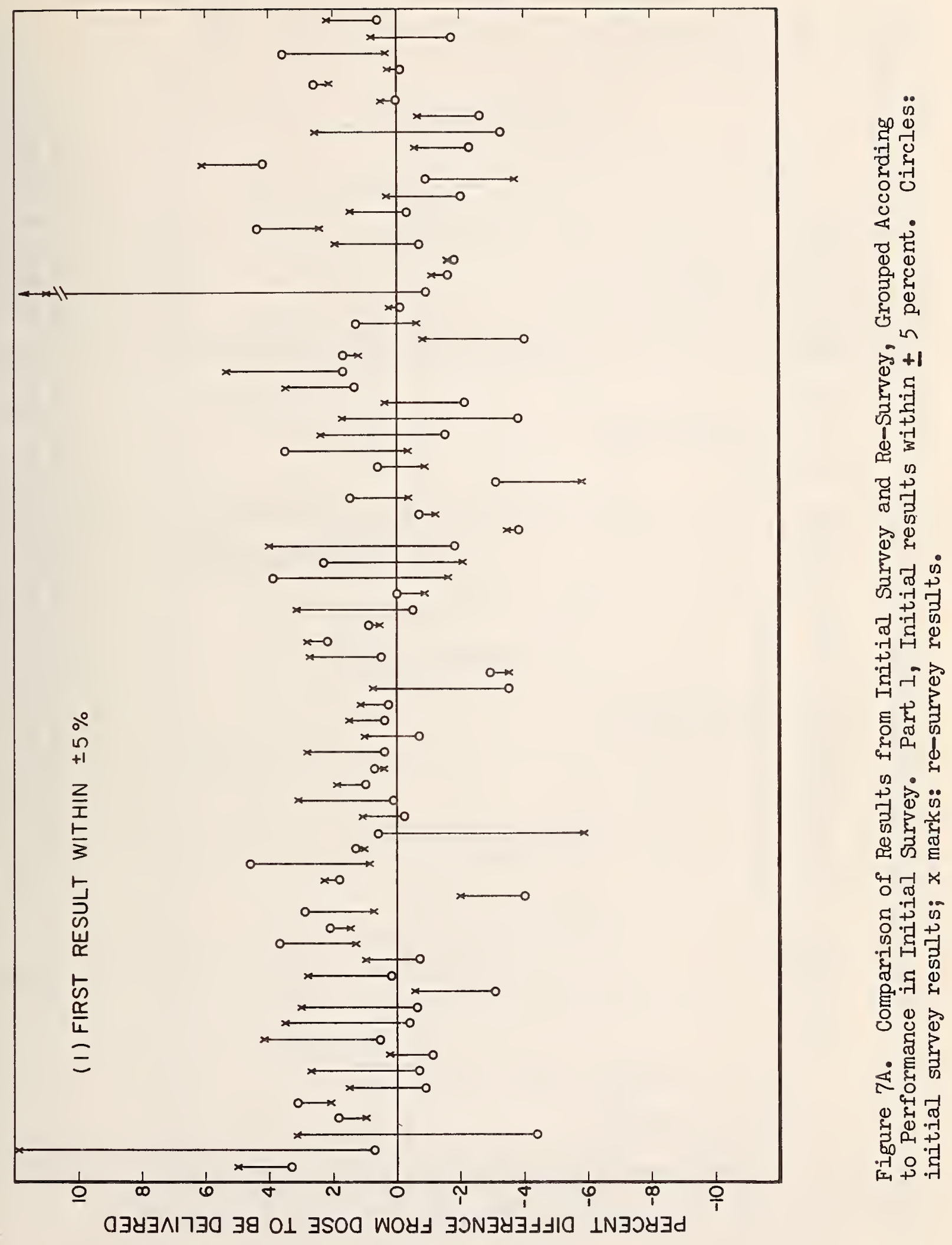



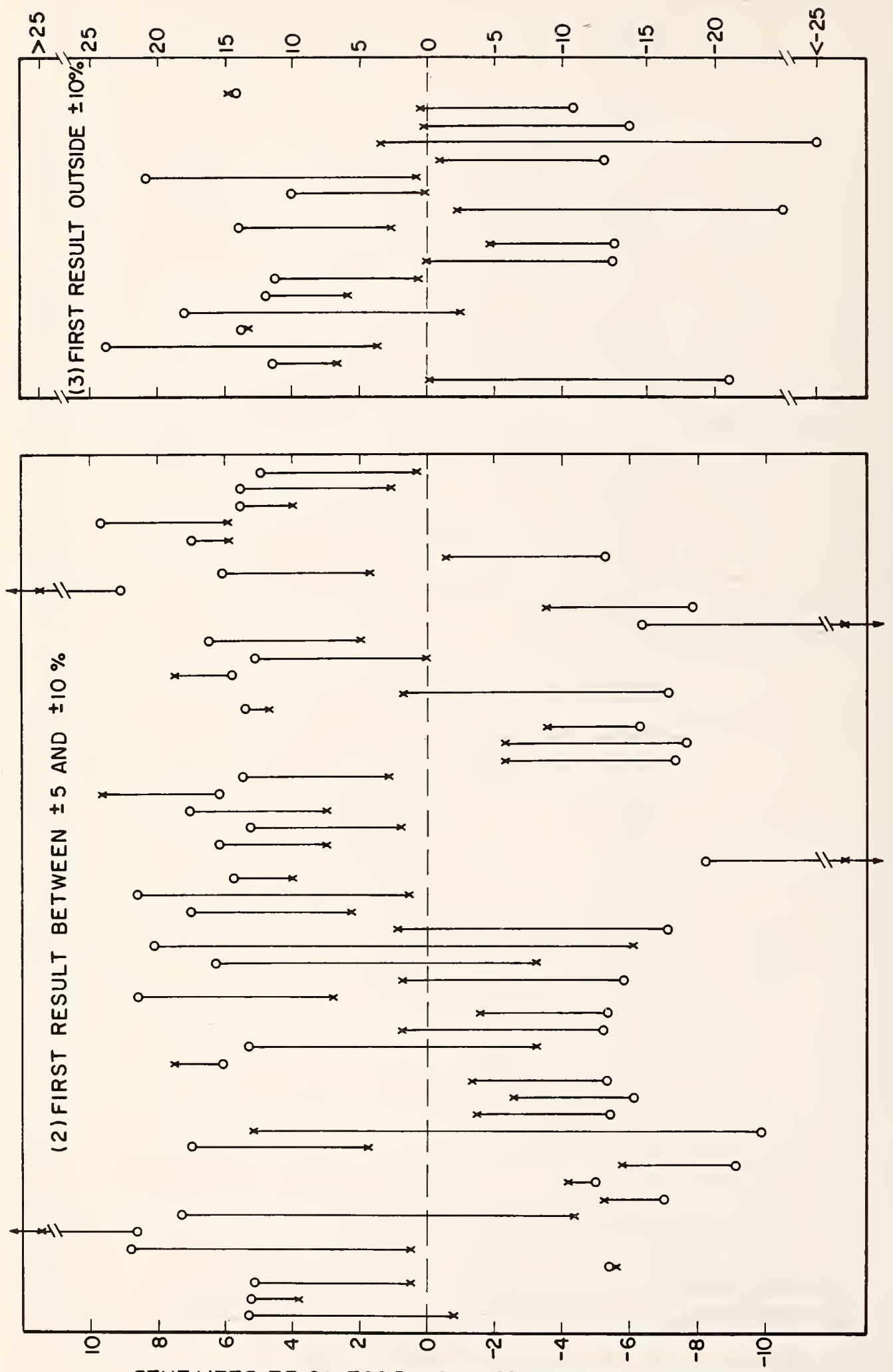

오유 을

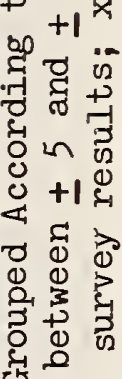

थै 开

(2)

हो

फิ

1)

(1) is

है 0

ช્ટુ స్

तु

ब.

?

हैं 今

สี่

- तु

덜 \&

今

है द्न

द्ये है

फ द्ये

(2) $A_{1} 0$

$+$

.

थ $B$

记

क्ये

फ हึं +1

द्व तु

थ.

궁

त्र

O 1 U क

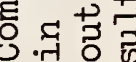

ه ్ㅕ

- ర్ష శ్

คี สี

व द्व

द्वैक्ष ठ ह 50 है द्व न्त 0 \&

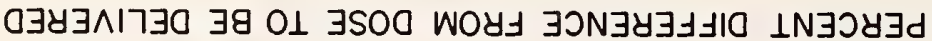




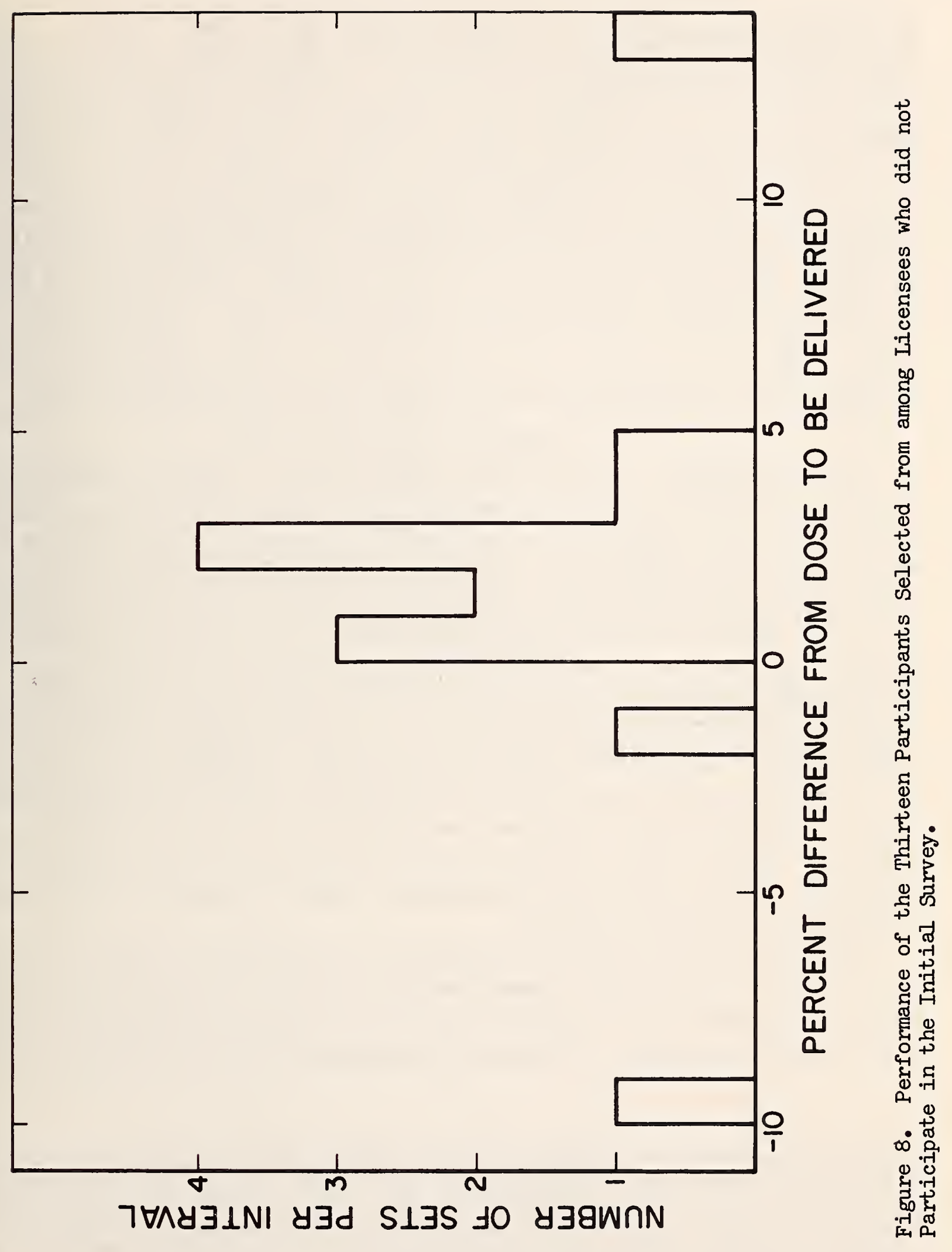


malfunctions. There even was a discrepancy that was traced by the participant to an error in the computer output upon which his dose-rate chart had been based. Most of the above errors could also occur during patient irradiation. It should be noted however that the exposure protocol for the dosimeters did not completely reflect the usual clinical setup and therefore a greater incidence of human error was to be expected, especially for individuals who were participating in the survey for the first time.

of interest also were the methods and factors used by the participants to derive absorbed-dose rate in water from the calibration data. Most participants calibrate in terms of exposure rate in air and use one of the first three methods shown in table 8 to convert to absorbed-dose rate. Examination of some of the early results

(2) indicated that a majority of the errors made in this conversion stemmed from a failure to apply one or more of the necessary factors, or from the use of incorrect factors. A full analysis of the results correlated with calibration method is being done by the Bureau of Radiological Health.

\section{COMPARISON WITH RESULTS OF OTHERS}

In the United States, the only other comprehensive survey somewhat comparable to that carried out by NBS was initiated on an emergency basis by the Nuclear Regulatory Commission (NRC) at a time when the NBS study was more than half completed. In this study, for which the portion comprising mailing of TL dosimeters was patterned after the NBS survey, all U.S. teletherapy users who could not show satisfactory results from a participation in another recognized independent national survey program (such as, e.g., the NBS-BRH voluntary survey here described) were made to participate. A total of 592 units was checked, of which about 64 percent were found to come within 5 percent of the requested dose.* Inasmuch as the results of this study showed a considerable bias in the direction toward delivery of lower doses than those requested, while no such bias was found in our study, it cannot be ruled out that this bias had its origin in the dosimetry system that had to be assembled rather hurriedly. Thus, the overall performance conceivably was better than indicated by the results. In states in which the NRC has inspection responsibilities, the mailed study was followed up by direct inspection and measurements, through which almost all the discrepancies could be satisfactorily resolved.

Preliminary results obtained at the Radiological Physics Center in Houston, in which all but three of the 230 units surveyed by mail were found to have delivered within 5 percent of the requested dose, mance throughout this country. These results were obtained during the first eight months

* The result quoted here is for both the states in which the NRC inspects the facilities of al1 their licensees ("non-agreement states") and for the states in which the state health departments have this function ("agreement states"). Both in the NBS and the NRC studies there was no significant difference in the performance of teletherapy users in the two categories of states. The NRC results quoted here are for both categories combined. The data for the non-agreement states were reported by Dicey et al.!3) The data for the agreement states are not as yet generally available. 
of a continuing survey of institutions involved in certain interinstitutional clinical trials. The institutions had been visited by physicists from the Center prior to being surveyed by mail--although in some instances not for some time. Earlier results obtained by this Center in personal visits to 174 institutions involved in clinical trials showed that of the 352 teletherapy units checked and of the 768 associated tumor-dose prescription protocols reviewed 88 percent were within 5 percent of the prescribed tumor dose. our own mailed TL dosimetry study, we found that 83 percent of the 906 units surveyed delivered doses to a water phantom that were within 5 percent of the requested dose. If one assumes that institutions involved in clinical trials are representative of all institutions administering teletherapy, this result would indicate that it is possible to obtain information from mailed TL dosimetry studies that correlates with that obtained in actual visits to the institutions.

Results obtained from a cross section of national institutions by a secondary-standard dosimetry laboratory are also available from India. (6) There, 19 of the 32 teletherapy units $(59 \%)$ came within 5 percent of the requested dose, and four had results differing by more than 10 percent. A continuing international survey is being conducted by the International Atomic Energy Agency in conjunction with the World Health Organization. The results for the years $1970-1975^{(7)}$ covering 417 measurements (including follow-ups on some of the participants) showed about 63 percent of the delivered doses to be within 5 percent of the requested dose and 15 percent to differ by more than 10 percent.

\section{ACKNOWLEDGEMENT}

The authors wish to express their appreciation to Mr. J. M. Cameron, chief, Office of Measurement Services (now retired) and to Dr. H. H. Ku, chief, Statistical Engineering Division, for their assistance with the analysis of the uncertainties in the NBS method for determining absorbed dose from dosimeter response. 


\section{REFERENCES}

1. Shukovsky, L. J., Dose, Time, Volume Relationships in Squamous Cell Carcinoma of the Supraglottic Larynx, Am. J. Roentgenol., Radium Therapy and Nuc1. Med. 108, 27-29 (1970).

2. Ehrlich, M., Welter, G. L., Nationwide Survey of ${ }^{60}$ Co Teletherapy Dosimetry, J. Res. Nat. Bur. Stand. (U.S.), 80 A, 663-668 (1976).

3. Dicey, B. B., Moe, H. J., and Tongue, T. M., Nationwide Evaluation of Teletherapy Calibrations: A Project Report presented at the Annual winter meeting of the American Association of Physicists in Medicine, Chicago, IL (1977); accepted for publication in Medical Physics.

4. Hanson, W. F., Radiological Physics Center of the University of Texas System Cancer Center, Houston, Texas, private communication.

5. Shalek, R. J., Kennedy, P., et al, Quality Assurance for Measurements in Therapy, Proceedings of the Symposium on Measurements for the Safe Use of Radiation, NBS SP 456, 111-118 (1976); for sale by the Superintendent of Documents, U.S. Government Printing Office, Washington, D.C. 20402

6. Sundararao, I. S., Naik, S. B., et al, Evaluation of Dosimetry Accuracy and Uniformity for ${ }^{60}$ Co Radiation Therapy, Proceedings of the International Symposium on National and International Standardization of Radiation Dosimetry, Atlanta, GA (1977); to be published by the International Atomic Energy Agency, Vienna, Austria.

7. Eisenlohr, H. H., and Jayaraman, S., IAEA-WHO Cobalt-60 Teletherapy Dosimetry Service Using Marked Dosimeters. A Survey of Results Obtained during 1970-75, Phys. Med. Biol. $22,18-28$ (1977). 


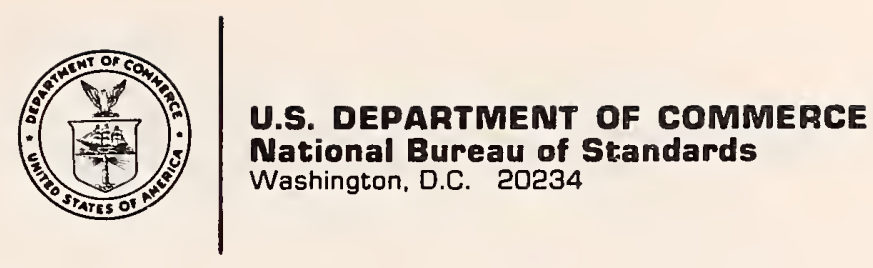

Table 1

Initial Inquiry Letter

As a part of a program of testing the National Measurement System, the National Bureau of Standards, in cooperation with the Bureau of Radiological Health, is undertaking a study to determine whether the NBS methods for making dosimetry standards available are adequate or need to be improved. For this purpose, we are conducting a test of the accuracy with which a prescribed dose of cobalt-60 gamma radiation is delivered to a specified point in a water phantom. This test will involve radiotherapy departments throughout the United States.

You are among those selected on a random basis for participation in this study, which will be performed at no cost to the participants. If you are willing to participate, several thermoluminescence dosimeters will be mailed to you for irradiation and subsequent return to us for evaluation. We will then inform you of our dose interpretation for the readings on the dosimeters, which is capable of revealing discrepancies of five percent or more. While our study cannot be considered in any way to take the place of a regular calibration of your unit, we believe that the information gained will be of value to you and will provide some compensation for your efforts.

Please indicate on the enclosed form whether or not you are willing to participate and, if you are, to whom all future correspondence should be directed, including the report of the results. Return the completed form in the enclosed stamped and addressed envelope. The performance of the individual participants in this study will not be disclosed by us to anyone, and only anonymous statistical compilations of the results will be reported to the Bureau of Radiological Health or otherwise made public.

\footnotetext{
sincerely,

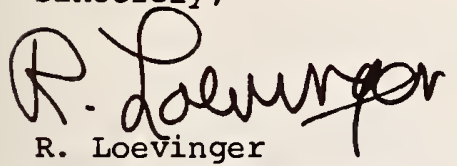

R. Loevinger

Chief, Dosimetry Section

Center for Radiation Research
}

NOTE: A SELF-ADDRESSED STAMPED ENVELOPE IS ENCLOSED. 
I am

willing to participate in the NBS ${ }^{60}$ Co teletherapy dosimetry-

I am not

assurance study. (Please strike out the phrase that does not apply.)

I have $\frac{60}{\text { how many }}{ }^{60}$ teletherapy units.

Name and address for all future communications (please print or type):

Name :

Organization:

Street Address :

Telephone No. (Area Code)

(Date)

(Signature)

Note: If there are any times during the next few months when you would be unable to participate because of vacations or the like, please indicate. 


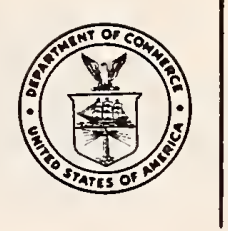

Table 3

Follow-up Inquiry Letter

We have not received your answer to our inquiry regarding your interest in cooperating in a cobalt-60 dosimetry survey. We are anxious to include in our survey a large fraction of the groups that we initially approached. We had selected these groups on a random basis from among a 11 those owning cobalt-60 teletherapy equipment. If a large number of those approached were not to participate, the validity of the conclusions drawn from our survey results would suffer.

In case you meant to participate but happened not to return the first questionnaire, please mail the one enclosed with this note, if possible some time before

For your convenience, we also are sending you a self-addressed envelope that needs no stamp.

Sincerely,

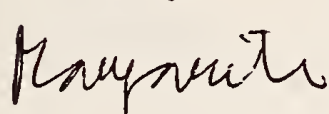

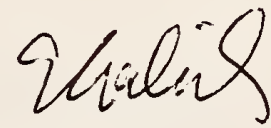

Margarete Ehrlich, Physicist Dosimetry Section

Center for Radiation Research

Enclosures 
Table 4

Announcement of Dosimeter Mailing

Thank you for letting us know that you are willing to participate in our comparison of dose calibrations of ${ }^{60} \mathrm{Co}$ gamma-ray therapy units. We should like to reemphasize that this study will be carried out free of charge, that it is confidential, and that only anonymous statistical compilations of the results will be made public, but that each participant will be notified of his own results.

On or about one set each of six dosimeters per ${ }^{\mathrm{Co}} 60$ teletherapy unic will be mailed to you. The dosimeters consist of $\mathrm{CaF}_{2}: \mathrm{Mn}$ thermoluminescence material in glass bulbs, contained in black plastic blocks. Five of the six dosimeters are for irradiation, one is a control that should be kept away from radiation at all times. Please do not open the black blocks. The bulbs inside are lightsensitive and fragile. Along with the dosimeters, we are going to mail you

\section{instructions;}

an exposure-information form;

a return-address label requiring no postage; and

a copy of this letter.

Please carry out the irradiations within three workdays of the receipt of the dosimeters. Follow the instructions in detail and return all dosimeters and the completed exposure-information form in the original mailing carton. Also, note that for the study to yield realistic results the dosimeter irradiations should be performed under conditions duplicating as closely as possible the routine patient irradiations and the individuals carrying out the irradiations should be those routinely involved in patient set-up and treatment.

We may not be able to evaluate the doses received by dosimeters reaching us after

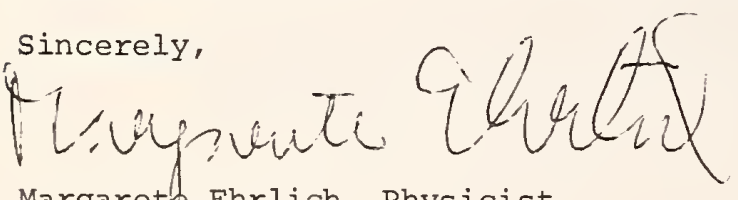

Margarete Ehrlich, Physicist

Dosimetry Section

Center for Radiation Research

telephone: (301) 921-2366 or 2361 


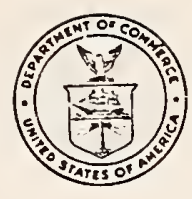

U.S. DEPARTMENT OF COMMERCE

National Bureau of Standards

Washington, D.C. 20234

Table 5

Page 1 of 3 pages

\section{Instructions for Irradiating the Dosimeters}

1- Please carry out the irradiations as soon as possible after the dosimeters arrive, if possible mailing them back within three working days.

2- When you are ready for the exposures, remove all six black plastic dosimeter blccks from the mailing carton. (Five of these are for irradiation, one is a contro1.) Take the mailing carton and one block at a time into the treatment room. Turn the carton on its side, place it on top of your treatment table, and center the block, screw heads up, on the carton.

3- Use your normal treatment distance unless it is smaller than $50 \mathrm{~cm}$, in which case use a distance of $50 \mathrm{~cm}$. If you normally measure your distance to the surface ("SSD Technigue"), follow the instructions in 3.1. If you normally measure distance to the tumor ("SAD Technique"), follow the instructions in 3.2 .

Please note that while the exposures are not to be made with the dosimeter blocks in a phantom, the absorbed-dose rate and the exposure time should be computed as if the dosimeters (located in the plane of the crack in the block) were at a depth of $1 \mathrm{~cm}$ in a large water phantom.

Also note that for the study to yield realistic results the dosimeter irradiations should be performed under conditions duplicating as closely as possible the routine patient irradiations and the individuals carrying out the irradiations should be those routinely involved in patient set-up and treatment. 
Table 5, continued

Page 2 of 3 pages

Instructions for Irradiation the Dosimeters, cont.

\subsection{SSD Technique (See Sketch 3.1)}

a- Measure the source-surface distance to the proximai surface of the block.

$\mathrm{b}$-Set the field size at the measured distance to $10 \mathrm{~cm} \times 10 \mathrm{~cm}$. c- Set the timer to deliver 300 rads calculated at a $1 \mathrm{~cm}$ depth in water (soft tissue*) and expose.

d- Proceed with step 4.

SKETCH 3.1, SSD Technique

SKETCH 3.1, SSD Technique

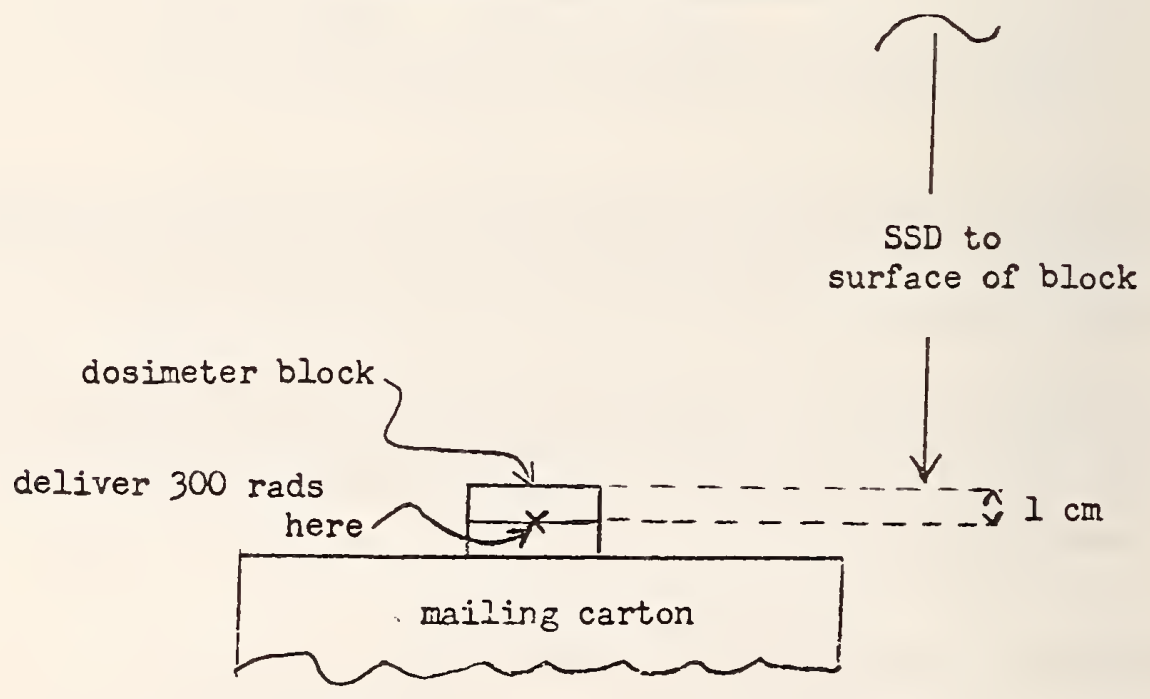

*For this study, absorbed dose in water and in soft tissue will be assumed to be the same. 


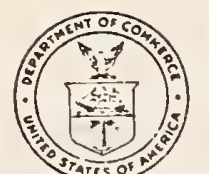 \\ Table 5, continued \\ Page 3 of 3 Pages \\ U.S. DEPARTMENT OF COMMERCE National Bureau of Standards Washington, D.C. 20234 \\ Instructions for Irradiating the Dosimeters, cont. \\ 3.2 SAD Technique (See Sketch 3.2) \\ a- Measure the source-axis (or source-tumor) distance to the center of the block (where the crack is), i.e., I cm below the surface. \\ b- Set the field size at the measured distance to $10 \mathrm{~cm} \times 10 \mathrm{~cm}$. \\ c- Set the timer to deliver 300 rads calculated at a $1 \mathrm{~cm}$ depth in water (scit tissue*) ard exposi.}

d- Proceed with step 4.

\section{SKETCH 3.2, SAD Technique}

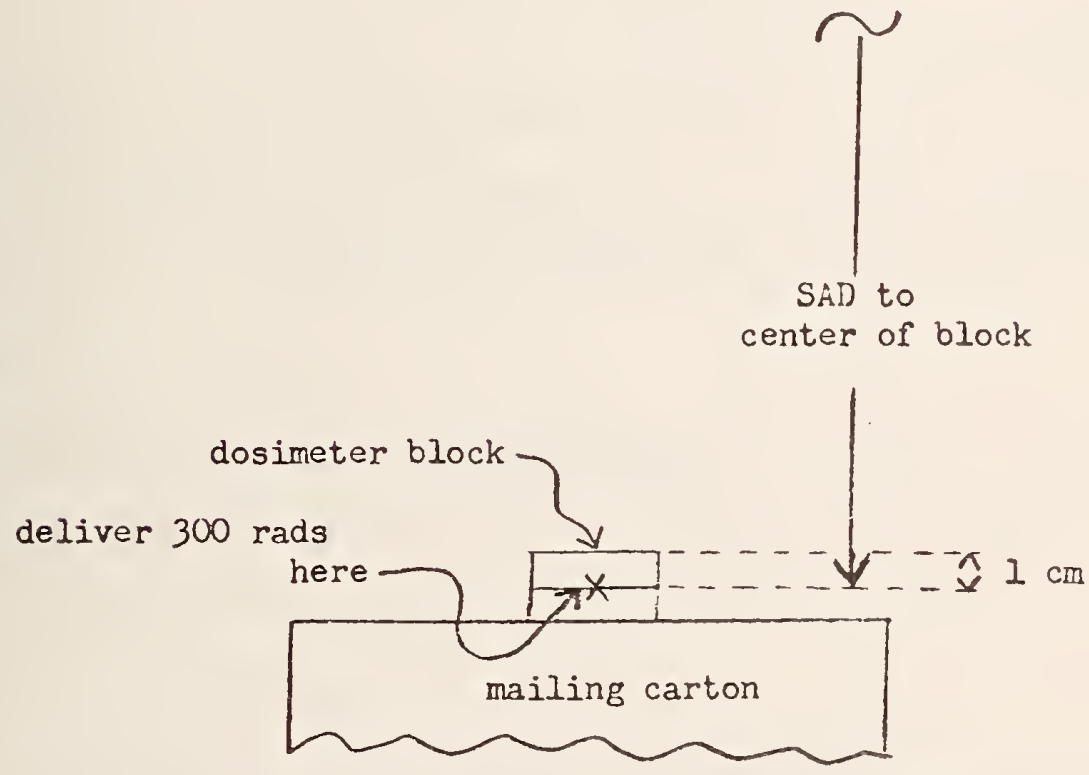

4- Irradiate five of the six blocks identically. One block must remain unexpused to serve as a control.

5- Fill out the Irradiation-Information Form completely(three pages). If possible, have your physicist complete pages 2 and 3 . The information on these pages would enable us to determine how absorbed-dose rate and exposure time for the irradiation of the NBS dosineters were obtained.

6- Place all.six dosimeter blocks and the exposure-information form back into the mailing carton and return the carton to us by mail, using the enclosed address label which requires no postage.

*For this study, absorbed dose in water and in soft tissue will be assumed to be the same. 


\section{IRRADIATION INFORMATION FORM}

\section{(TO BE RETURNED WITH THE DOSIMETERS)}

I. Please supply all pertinent information on this page; then proceed to pages 2 and 3. The information on this page is essential to the interpretation of the dosimeter readings; therefore this page should be returned with the dosimeters. Pages 2 and 3 may be returned at a later date.

Date of irradiation:

Time of day of irradiation:

Distance to dosimeter-block surface, $\mathrm{SSD}=$ cm or

Distance to point at which 300 rads delivered, $\mathrm{SAD}=$ cm.

Field size at specified distance cm $\mathrm{x}$ $\mathrm{cm}$.

Irradiation time (actual time, not corrected timer setting): $\min$ sec.

Dosimeters exposed by

$$
\text { (name, title) }
$$

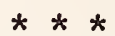

This page was filled out by

(name, title)

on

(date)

PIEASE DC NOT FORGET TO RETURN THE PACKAGE CERTIFISD MAIL AND TO OBTAIN AND SAFE-KEEP THE CERTIPIED KAIL NUMBER 
II. Please supply all pertinent information on this and the next page, if possible. If there is a significant difference between our dose interpretation and the dose that you believe you delivered to the dosimeters, the information on these pages will enable us to determine if this difference is due to calculation error.

1- Type of machine mount (circle one): Vertical Isocentric

2- Calibration

The unit was last calibrated (fill in whichever is applicable):

2.1 in terms of exposure rate (no phantom) for a field size of $\mathrm{cm} x$ $\mathrm{cm}$. at a distance of $\mathrm{cm}$; exposure rate: $\mathrm{R} / \mathrm{min}$ on (date);

2.2 in terms of exposure rate in a large phantom ${ }^{1}$ for a field size of $\mathrm{cm} \times$ cm, at a SSD of $\mathrm{cm}$, at a depth of $\mathrm{cm}$; exposure rate: $\mathrm{R} / \mathrm{min}$ on (date);

2.3 in terms of absorbed-dose rate in an equilibrium mass of water ${ }^{2}$ ("minizhantom") for a field size of $\mathrm{cm} \times$ $\mathrm{cm}$, at a distance of $\mathrm{cm}$ to the center of the miniphantom; absorbed-dose rate: $\mathrm{rad} / \mathrm{min}$ on (date) ;

2.4 in terms of absorbed-dose rate in a large phantom ${ }^{1}$

for a field size of $\mathrm{cm} x$ Cm, at a SSD of cm, at a depth of cm; absorbed-dose rate: $\mathrm{rad} / \mathrm{min}$ on (date).

2.5 other (specify):

3- Absorbed-Dose Computation

\subsection{Factors used}

Please note: Not all of the factors listed can be used in any one calculation. Do not specify values for factors that you did not use.

3.1.1 Source-decay correction for time elapsed between calibration and irradiation date:

${ }^{1}$ please specify phantom material (check one or write in):
Water
Polystyrene
Lucite
Other:

${ }^{2}$ For ${ }^{60}$ Co radiation, a sphere of water of $0.5 \mathrm{~cm}$ radius is an equilibrium mass, i.e., just large enough for electronic equilibrium. 


\subsection{Factors used, continued}

3.1.2 Exposure-to-absorbed-dose conversion factors

F factor:

f factor:

$c_{\lambda}$

attenuation correction:

(cap correction, 'A $C$ ' $\mathrm{A}_{\mathrm{eq}}$ '

displacement correction:

others:

3.1.3 Inverse-square correction from cin to $\mathrm{cm}$ :

3.1.4 Tissue/air ratio:

3.1.5 (Back) scatter factor, i.e., buildup factor due to scatter in large phantom:

3.1.6 Percent depth dose:

3.1.7 Others (explain):

3.2 Result of computation of absorbed-dose rate for use in irradiation of the set of NBS dosimeter biocks:

Absorbed-dose rate at $1 \mathrm{~cm}$ depth in large water phantom: $\mathrm{rad} / \mathrm{min}$.

Pages 2 and 3 of this form filled out by on 


\section{Table 7}

Text of Report Sent to Participants

ACCURACY WITH WHICH A PRESCRIBED ABSORBED DOSE

OF COBALT-60 GAMMA RADIATION IS DELIVERED TO A SPECIFIED POINT IN WATER

Report on the Performance of the

Participants that were sent Dosimeters in

by

Margarete Ehrlich and Christopher Soares

Dosimetry Section, Center for Radiation Research

National Bureau of Standards

This study was undertaken under Interagency Agreement FDA-IAG 74-41 (0), Modification No. 1, between the National Bureau of Standards and the Food and Drug Administration, Bureau of Radiological Health. 
Attached are the results and some pertinent background data for the survey involving participants ( sets). The following information is supplied.

Table la* - A list of the major methods in use for computing absorbeddose rate at a depth of $1 \mathrm{~cm}$ in a water phantom from the calibration data of a cobalt-60 gamma-ray source referred to the date of irradiation. NBS used eq. (3) in the computation of absorbed-dose rate from exposure parameters for the NBS cobalt-60 calibration source. For checking the participants' computed doses, NBS used the numerical values listed in Table $1 \mathrm{~b}$ for the pertinent parameters and constants.

Table $1 b^{*}$ - A list of symbols used in Table la and of values for pertinent parameters and constants.

Table 2 - This table contains the following information:

(a) A list of the individual absorbed-dose interpretations obtained for all irradiated dosimeters, the average dose interpretation for each participant, and the percent difference, $\Delta$, between the NBS dose interpretation and the dose to be delivered ( 300 rads in water, unless otherwise indicated). Note that the red arrow points to the results of the participant to whom this report is being mailed.

Absorbed dose was computed from the readings of the dosimeters irradiated by the participants after suitable corrections for differences in individual dosimeter sensitivity, and for fading. Differences $\triangle$ outside the NBS overall error limits (see below) are an indication of wrong source calibration or of wrong delivery parameters (such as, faulty positioning, wrong field size, wrong timer setting, faulty timer) or of improper computation (such as wrong equations, wrong values for the parameters and constants, errors in arithmetic).

* In this paper shown as tables 8 and 9. 
(b) A list of the doses computed by NBS from the information supplied by the participants, and of the methods according to which the computations were carried out. A discrepancy between the computed dose and the dose to be delivered (300 rads in water, unless otherwise indicated) is an indication of improper computation.

Figure 1 - This is a histogram of the percen $\imath$ difference, $\Delta$, between the average NBS dose interpretation obtained from all the individual inter.pretations for a participant, and the dose to be delivered (300 rads).

Details on the dosimetry system used and on the method of dose evaluation will be published in the future, along with a review of typical survey results. At this point, it suffices to state the following results of our error analysis:

1 - The bound for the total systematic error of our method is estimated to be $\sim 2^{\frac{1}{2}}$ percent.

2 - The bound for the total randon error in our dose interpretation is estimated to be

a - $\sim 3$ percent for readings on a single dosimeter;

b - $I_{1} \frac{1}{2}$ percent for the average of readings on five dosimeters.

3 - Therefore, the overall error in the average NBS dose interpretation for readings on five dosimeters is estimated to be less than 4 percent.

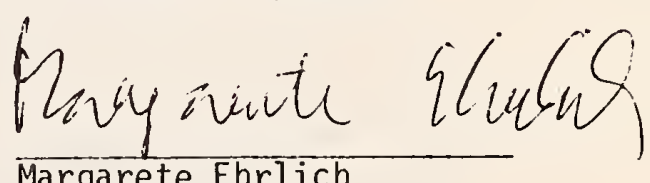

$\overline{\text { Date }}$

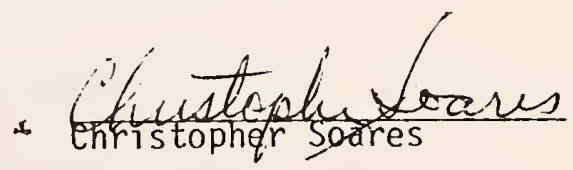


Table 8

Method for Computing Absorbed-Dose Rate at a

Depth of $1 \mathrm{~cm}$ in a Water Phantom

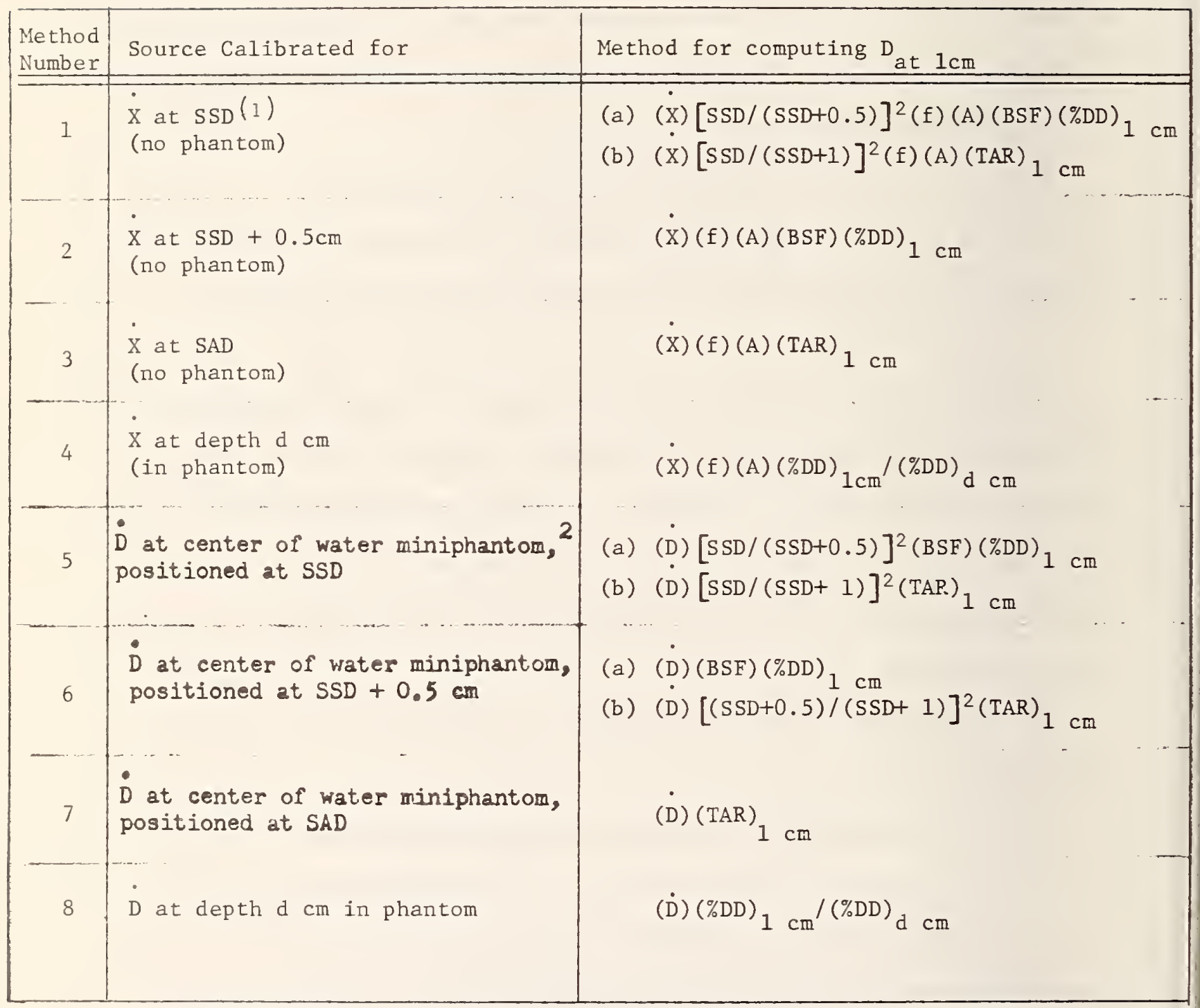

(1) All distances are in cm.

(2) For ${ }^{60}$ Co garma rays, a water sphere of $0.5 \mathrm{~cm}$ radius is a "miniphantom", 1.8., a phantom just large enough for establishing electronic equilibrium at its center. 
Table 9

Parameters and Constants Entering Into

Absorbed-Dose Computations

\begin{tabular}{|c|c|c|}
\hline Symbo1 & Quantity & $\begin{array}{l}\text { Value and source, } \\
\text { where applicable }\end{array}$ \\
\hline$\dot{\mathrm{x}}$ & exposure rate & -- \\
\hline$\dot{\mathrm{D}}$ & absorbed-dose rate & -- \\
\hline SSD & source-to-surface distance & - \\
\hline $\mathrm{SAD}$ & source-to-axis distance & -- \\
\hline $\mathrm{f}$ & $\begin{array}{l}\text { (D) }{ }_{\text {water }} /(\dot{X})_{\text {air }} \text {, obtained under electron } \\
\text { equilibrium conditions }\end{array}$ & $0.965,^{(1)} \operatorname{ICRU}(2)$ \\
\hline A & attenuation correction, cap correction, etc. & $\begin{array}{l}0.985 \text {, Johns and } \\
\text { Cunningham }(3)\end{array}$ \\
\hline F & (f) (A) & -- \\
\hline BSF & (back) scatter factor & BJR Supplement ${ }^{(4)}$ \\
\hline \%DD & percent depth dose & BJR Supplement $(4)$ \\
\hline TAR & tissue/air ratio & BJR Supplement ${ }^{(5)}$ \\
\hline
\end{tabular}

(1) We use the value for water in our calculations for this survey. For soft tissue, the corresponding ratio is 0.957 .

(2) Table IV.1, ICRU Report 10d(NBS HB 87), 1963.

(3) Table IX.1, p. 274, The Physics of Radiology, Third Edition, 1969.

(4) Tables 6.1 through 6.4, BJR Supplement No. 11, 1972.

(5) Table 6.5, BJR Supplement No. 11, 1972. 
Systematic Uncertainty

NBS exposure calibration of Co-60 Gamma-ray source . . . . $0.7 \%$

Uncertainty in dosimeter calibration . . . . . . . 0.7\%

Uncertainty in dosimeter fading correction . . . . . . 1.0\% Total . . . . . . . . . . . $2.4 \%$

Random Uncertainty

Reproducibility of individual dosimeter response (3S). . $2.4 \%$

Correction for sensitivity variation between dosimeters . $2.4 \%$

Total for corrected individual dosimeter response - $3.4 \%$

Total for average corrected'response of five dosimeters . . . . . . . . . . . . $1.5 \%$

Total Uncertainty in dose interpretation from average of five dosimeters . . . . . . . . . . $~ 24.0 \%$ 


\begin{tabular}{|c|c|c|}
\hline $\begin{array}{l}\text { 1. PUBLICATION OR REPORT NO. } \\
\text { NBS TN } 978\end{array}$ & $\begin{array}{l}\text { 2. Gov't Accession } \\
\text { No. }\end{array}$ & 3. Recipient's Accession No. \\
\hline \multirow{2}{*}{\multicolumn{2}{|c|}{$\begin{array}{l}\text { 4. TITLE AND SUBTITLE } \\
\text { Nationwide Survey of Coba } 1 t-60 \text { Teletherapy Dosimetry }\end{array}$}} & $\begin{array}{l}\text { 5. Publication Date } \\
\text { August } 1978\end{array}$ \\
\hline & & 6. Performing Organization Code \\
\hline $\begin{array}{l}\text { 7. AUTHOR(S) } \\
\text { C. G. Soares and M. Ehrlich }\end{array}$ & & 8. Performing Organ. Report No. \\
\hline \multirow{2}{*}{\multicolumn{2}{|c|}{$\begin{array}{l}\text { 9. PERFORMING ORGANIZATION NAME AND ADDRESS } \\
\text { NATIONAL BUREAU OF STANDARDS } \\
\text { DEPARTMENT OF COMMERCE } \\
\text { WASHINGTON, D.C. } 20234\end{array}$}} & 10. Project/Task/Work Unit No. \\
\hline & & 11. Contract/Grant No. \\
\hline \multirow{2}{*}{\multicolumn{2}{|c|}{$\begin{array}{l}\text { 12. Sponsoring Organization Name and Complete Address (Street, City, State, ZIP) } \\
\text { Radioactive Materials Branch } \\
\text { Bureau of Radiological Health } \\
\text { Rockville, Maryland } 20852\end{array}$}} & $\begin{array}{l}\text { 13. Type of Report \& Period } \\
\text { Covered }\end{array}$ \\
\hline & & 14. Sponsoring Agency Code \\
\hline
\end{tabular}

\section{SUPPLEMENTARY NOTES}

16. ABSTRACT (A 200-word or less factual summary of most significant information. If document includes a significant bibliography or literature survey, mention it here.)

Between September 1974 and December 1977 the National Bureau of Standards, in cooperation with the Bureau of Radiological Health, performed a study of the accuracy with which a prescribed absorbed dose of cobalt-60 gamma radiation is delivered to a specified point in a water phantom. Approximately two-thirds of the cobalt-60 teletherapy units in the U.S. were surveyed by mail, using a rugged thermoluminescence dosimetry system. The dose given by participants was evaluated from dosimeter response, and information supplied by participants was used to check their computations of the dose delivered. In this nationwide study, 83 percent of the units surveyed yielded dose interpretations within 5 percent of the requested dose, 13 percent yielded differences between 5 and 10 percent, and 4 percent of the dose interpretations differed by more than 10 percent from the dose requested. Sources of discrepancies are discussed, and the results of this survey are compared with those of other dosimetry surveys.

7. KEY WORDS (six to twelve entries; alphabetical order; capitalize only the first letter of the first key word unless a proper name; separated by semicolons)

Absorbed dose; cobalt-60 gamma radiation; computation check; dose interpretation; mailings; survey; teletherapy; thermoluminescence dosimeters; water phantom

\begin{tabular}{|c|c|c|}
\hline $\begin{array}{l}\text { 8. AVAILABILITY Unlimited } \\
\square \text { For Official Distribution. Do Not Release to NTIS }\end{array}$ & $\begin{array}{l}\text { 19. SECURITY CLASS } \\
\text { (THIS REPURT) } \\
\text { UNCL ASSIFIED }\end{array}$ & $\begin{array}{l}\text { 21. NO. OF PAGES. } \\
40\end{array}$ \\
\hline $\begin{array}{l}\text { Order From Sup. of Doc., U.S. Government Printing Office } \\
\text { Washington, D.C. } 20402, \text { SD Stock No. SN003-003-0I968-2 } \\
\square \text { Order From National Technical Information Service (NTIS) } \\
\text { Springfield, Virginia 22151 }\end{array}$ & $\begin{array}{l}\text { 20. SECURITY CLASS } \\
\text { (THIS PAGE) } \\
\text { UNCLASSIFIED }\end{array}$ & $\begin{array}{l}\text { 22. Price } \\
\$ 1.60\end{array}$ \\
\hline
\end{tabular}





\section{Where can you find all the reference data you need? \\ (a)}

Right in the Journal of Physical and Chemical Reference Data!

Now in its sixth year, this valuable publication has proved that it fills the important gaps for you in the literature of the physical sciences.

Published by the American Institute of Physics and the American Chemical Society for the National Bureau of Standards, this quarterly gives you quantitative numerical data, with recommended values and uncertainty limits chosen by experts in the field.

Critical commentary on methods of measurement and sources of error, as well as full references to the original literature, is an integral part of each of your four issues a year.

Can you afford to be without this prime source of reliable data on physical and chemical properties? To start receiving your copies, just fill in the order form and drop into the mail. If you oo use a purchase order, please attach the printed form as this will help us to expedite your order. Send for complete list of reprints!

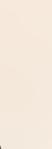
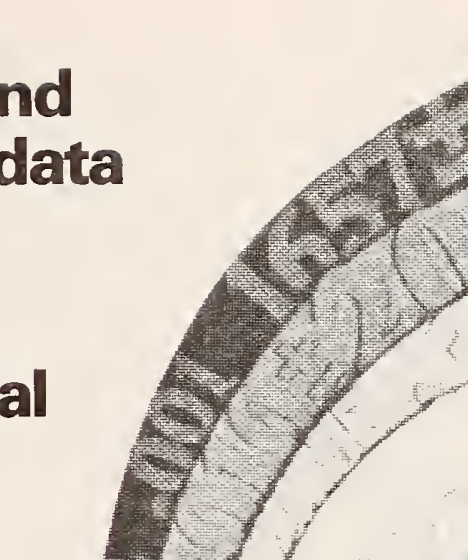

Journal of Physical and Chemical Reference Data

American Chemical Society

1155 Sixteenth Street,N.W., Washington, D.C. 20036

Yes, I would like to receive the JOURNAL OF PHYSICAL AND CHEMICAL REFERENCE DATA at the one-year rate checked below:

$$
\begin{aligned}
& \mathrm{Ne} \\
& \mathrm{St} \\
& \mathrm{Ci} \\
& \mathrm{Bi}
\end{aligned}
$$

Name

Street

$\square$ Home

$\square$ Business

city

State Zip

Payment enclosed $\square$
Members Nonmembers

U.S., Canada, $\square \$ 25.00 \square \$ 90.00$ Mexico

Other Countries $\square \$ 29.00 \quad \square \$ 94.00$

Please Attach This Order Form To Purchase Order. 



\section{NBS TECHNICAL PUBLICATIONS}

\section{PERIODICALS}

JOURNAL OF RESEARCH-The Journal of Research of the National Bureau of Standards reports NBS research and development in those disciplines of the physical and engineering sciences in which the Bureau is active. These include physics, chemistry, engineering, mathematics, and computer sciences. Papers cover a broad range of subjects, with major emphasis on measurement methodology, and the basic technology underlying standardization. Also included from time to time are survey articles on topics closely related to the Bureau's technical and scientific programs. As a special service to subscribers each issue contains complete citations to all recent NBS publications in NBS and nonNBS media. Issued six times a year. Annual subscription: domestic $\$ 17.00$; foreign $\$ 21.25$. Single copy, $\$ 3.00$ domestic; $\$ 3.75$ foreign.

Note: The Journal was formerly published in two sections: Section A "Physics and Chemistry" and Section B "Mathematical Sciences."

\section{DIMENSIONS/NBS}

This monthly magazine is published to inform scientists, engineers, businessmen, industry, teachers, students, and consumers of the latest advances in science and technology, with primary emphasis on the work at NBS. The magazine highlights and reviews such issues as energy research, fire protection, building technology, metric conversion, pollution abatement, health and safety, and consumer product performance. In addition, it reports the results of Bureau programs in measurement standards and techniques, properties of matter and materials, engineering standards and services, instrumentation, and automatic data processing.

Annual subscription: Domestic, $\$ 11.00$; Foreign $\$ 13.75$

\section{NONPERIODICALS}

Monographs-Major contributions to the technical literature on various subjects related to the Bureau's scientific and technical activities.

Handbooks-Recommended codes of engineering and industrial practice (including safety codes) developed in cooperation with interested industries, professional organizations, and regulatory bodies.

Special Publications-Include proceedings of conferences sponsored by NBS, NBS annual reports, and other special publications appropriate to this grouping such as wall charts, pocket cards, and bibliographies.

Applied Mathematics Series-Mathematical tables, manuals, and studies of special interest to physicists, engineers, chemists, biologists, mathematicians, computer programmers, and others engaged in scientific and technical work.

National Standard Reference Data Series-Provides quantitative data on the physical and chemical properties of materials, compiled from the world's literature and critically evaluated. Developed under a world-wide program coordinated by NBS. Program under authority of National Standard Data Act (Public Law 90-396).
NOTE: At present the principal publication outlet for these data is the Journal of Physical and Chemical Reference Data (JPC'RD) published quarterly for NBS by the American Chemical Society (ACS) and the American Institute of Physics (AIP). Subscriptions, reprints, and supplements available from ACS, 1155 Sixteenth St. N.W., Wash., D.C. 20056.

Building Science Series-Disseminates technical information developed at the Bureau on building materials, components, systems, and whole structures. The series presents research results, test methods, and performance criteria related to the structural and environmental functions and the durability and safety characteristics of building elements and systems. Technical Notes-Studies or reports which are complete in themselves but restrictive in their treatment of a subject. Analogous to monographs but not so comprehensive in scope or definitive in treatment of the subject area. Often serve as a vehicle for final reports of work performed at NBS under the sponsorship of other government agencies. Voluntary Product Standards-Developed under procedures published by the Department of Commerce in Part 10, Title 15, of the Code of Federal Regulations. The purpose of the standards is to establish nationally recognized requirements for products, and to provide all concerned interests with a basis for common understanding of the characteristics of the products. NBS administers this program as a supplement to the activities of the private sector standardizing organizations.

Consumer Information Series-Practical information, based on NBS research and experience, covering areas of interest to the consumer. Easily understandable language and illustrations provide useful background knowledge for shopping in today's technological marketplace.

Order above NBS publications from: Superintendent of Documents, Government Printing Office, Washington, D.C. 20402.

Order following NBS publications-NBSIR's and FIPS from the National Technical Information Services, Springfield, Va. 22161.

Federal Information Processing Standards Publications (FIPS PUB) - Publications in this series collectively constitute the Federal Information Processing Standards Register. Register serves as the official source of information in the Federal Government regarding standards issued by NBS pursuant to the Federal Property and Administrative Services Act of 1949 as amended, Public Law 89-306 (79 Stat. 1127), and as implemented by Executive Order 11717 (38 FR 12315, dated May 11, 1973) and Part 6 of Title 15 CFR (Code of Federal Regulations).

NBS Interagency Reports (NBSIR)-A special series of interim or final reports on work performed by NBS for outside sponsors (both government and non-government). In general, initial distribution is handled by the sponsor; public distribution is by the National Technical Information Services (Springfield, Va. 22161) in paper copy or microfiche form.

\section{BIBLIOGRAPHIC SUBSCRIPTION SERVICES}

The following current-awareness and literature-survey bibliographies are issued periodically by the Bureau:

Cryogenic Data Center Current Awareness Service. A literature survey issued biweekly. Annual subscription: Domestic, $\$ 25.00$; Foreign, $\$ 30.00$.

Liquified Natural Gas. A literature survey issued quarterly. Annual subscription: $\$ 20.00$.
Superconducting Devices and Materials. A literature survey issued quarterly. Annual subscription: $\$ 30.00$. Send subscription orders and remittances for the preceding bibliographic services to National Bureau of Standards, Cryogenic Data Center (275.02) Boulder, Colorado 80302. 
U.S. DEPARTMENT OF COMMERCE

National Bureau of Standards

Washington, O.C. 20234

OFFICIAL BUSINESS

U.S. DEPARTMENT OF COMMERCE

COM-2:5

Penalty for Private Use, $\$ 300$

SPECIAL FOURTH-CLASS RATE

BOOK 